\title{
Hydrogen-Activating Models of Hydrogenases
}

Tao $\mathrm{Xu}^{1}$, Dafa Chen ${ }^{2}$, and Xile $\mathrm{Hu}^{1, *}$

${ }^{1}$ Laboratory of Inorganic Synthesis and Catalysis, Institute of Chemical Science and

Engineering, Ecole Polytechnique Fédéral de Lausanne (EPFL), EPFL-SB-ISIC-LSCI, BCH

3305, 1015 Lausanne, Switzerland. E-mail: xile.hu@epfl.ch Tel. +41216939781

${ }^{2}$ School of Chemical Engineering and Technology, Harbin Institute of Technology, 150001

Harbin, China. 


\title{
Contents
}

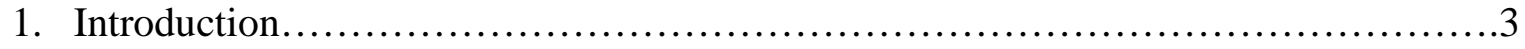

2. Reactions of [NiFe]-hydrogenase models with hydrogen............................

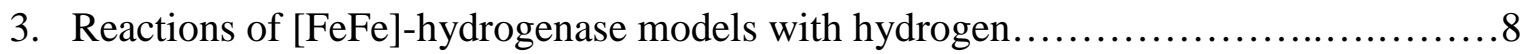

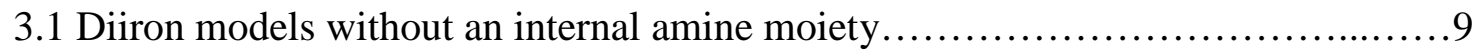

3.2 Diiron complexes with an internal amine moiety............................... 12

3.3 Bio-inspired complexes with an internal amine moiety............................ 15

4. Reactions of [Fe]-hydrogenase models with hydrogen...............................16

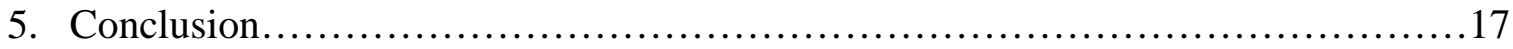

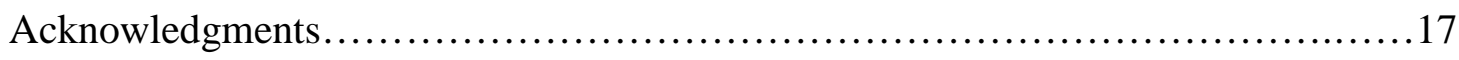

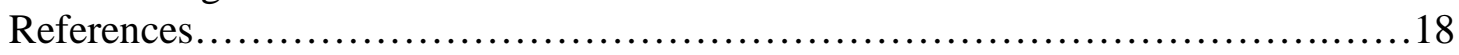

\begin{abstract}
Hydrogenases are biological catalysts for hydrogen evolution and activation. While many model complexes of hydrogenases can catalyze the hydrogen evolution reaction, few of them can react with hydrogen. Here we review the hydrogen-activating models of hydrogenases, in particular, [NiFe]- and [FeFe]-hydrogenases. The mechanism of these reactions is described.
\end{abstract}

\section{Keywords}

Hydrogenase; bio-mimetic chemistry; hydrogen activation; mechanism 


\section{Introduction}

Hydrogenases are enzymes that catalyze the production and consumption of hydrogen [1-6]. Hydrogenases were discovered as early as 1930 's, but their crystal structures have only been known in the last two decades [7-13]. Based on the structures of the active sites, hydrogenases are classified as [FeFe]-, [NiFe]- and [Fe]-hydrogenases [1,4-6].

The crystal structures of [FeFe]-hydrogenase were first determined in 1998 and 1999, and showed an active site made of a homodinuclear $\mathrm{Fe}_{2}(\mathrm{CO})_{3}(\mathrm{CN})_{2}$ core bridged by a $\mathrm{SCH}_{2} \mathrm{XCH}_{2} \mathrm{~S}\left(\mathrm{X}=\mathrm{CH}_{2}, \mathrm{NH}\right.$ or $\mathrm{O}$ ) dithiolate ligand (Figure 1, left) [7-9]. Since then, its structure and mechanism have been subjected to many studies [14-19]. In 2013, Berggren et al. introduced three synthetic complexes $\left[\mathrm{Fe}_{2}\left(\mathrm{SCH}_{2} \mathrm{XCH}_{2} \mathrm{~S}\right)(\mathrm{CO})_{4}(\mathrm{CN})_{2}\right]_{2}$ into the apoprotein of [FeFe]-hydrogenase, and only the semi-synthetic enzyme with $\mathrm{X}=\mathrm{NH}$ was active [20]. This result provided a strong confirmation that the bridging dithiolate ligand in the active site of [FeFe]-hydrogenase is an azadithiolate [20-22].

The crystal structures of [NiFe]-hydrogenases have been extensively studied by FontecillaCamps et al. [10-12, 23-25]. The active site of the oxygen sensitive [NiFe]-hydrogenases consists of a heterodinuclear [(' $\mathrm{S}$ ' $\left.)_{2} \mathrm{Ni}(\mu \text {-'S' })_{2}(\mu-\mathrm{X}) \mathrm{Fe}(\mathrm{CO})(\mathrm{CN})_{2}\right](\mathrm{S}=$ Cysteine, $\mathrm{X}=\mathrm{O}$ or $\mathrm{OH}$ ) fragment (Figure 1, middle). Recently, the crystal structure of a standard [NiFe] hydrogenase at $0.89 \AA$ resolution [26]. Both [FeFe]- and [NiFe]-hydrogenases catalyze the reversible conversion of $\mathrm{H}_{2}$ into protons and electrons (eq. 1).

$$
2 \mathrm{H}^{+}+2 \mathrm{e} \rightleftharpoons \mathrm{H}_{2} \quad \mathrm{Eq}^{\cdot} 1
$$
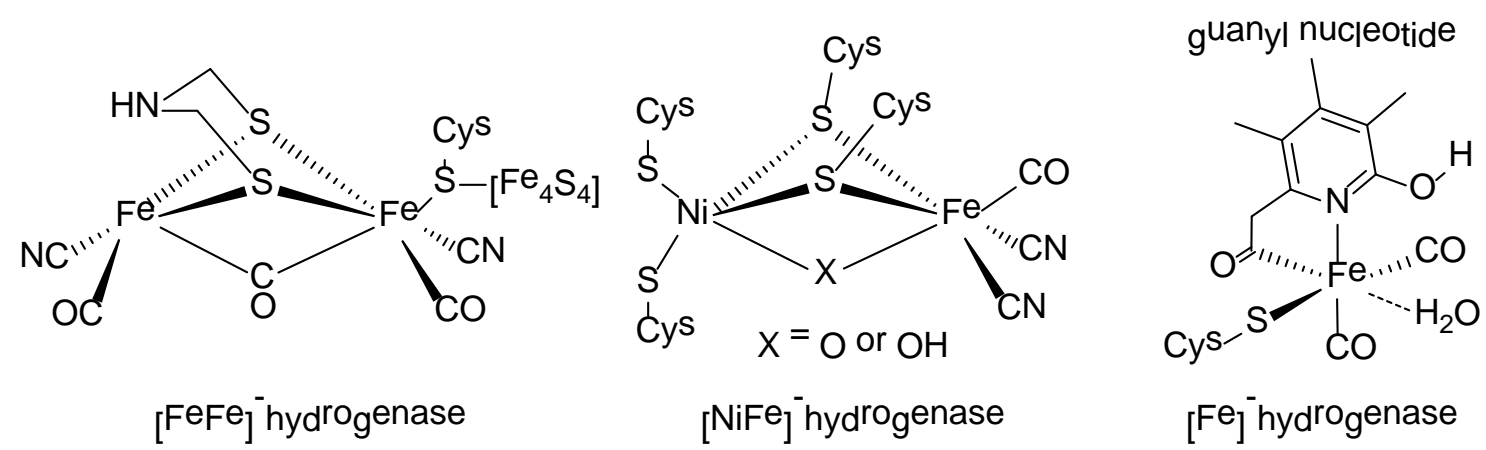

Figure 1. The active sites of three types of hydrogenases [7-13].

The [Fe]-hydrogenase is unique in both structure and activity. The active site of [Fe]hydrogenase contains only one Fe center coordinated by one cysteine sulfur, two cis-oriented $\mathrm{CO}$, and a bidentate guanylylpyridinol ligand (Figure 1, right) [13]. [Fe]-hydrogenase does not catalyze the hydrogen production and activation reactions described in eq. 1 . Instead, it catalyzes the hydrogenation of methenyltetrahydromethanopterin (methenyl- $\mathrm{H}_{4} \mathrm{MPT}^{+}$) to form methylenetetrahydromethanopterin (methylene- $\mathrm{H}_{4} \mathrm{MPT}$ ) and proton, respectively (Scheme 1) $[4-6,27,28]$. 


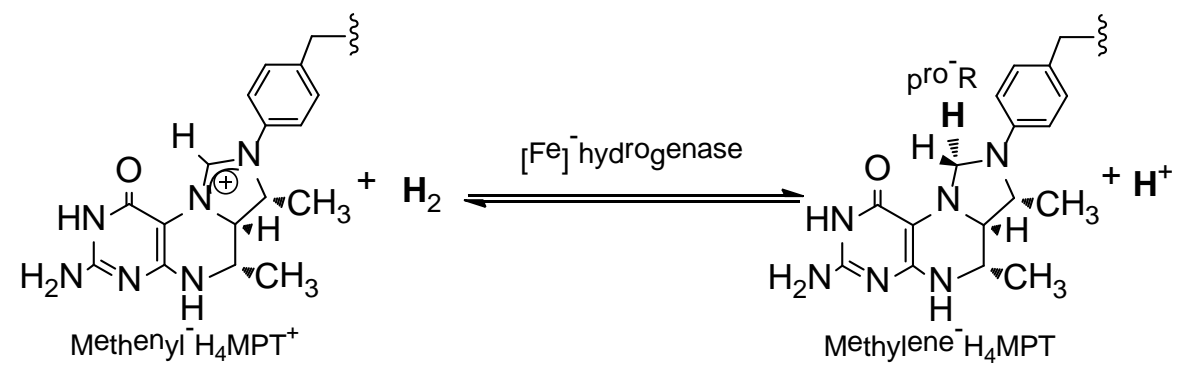

Scheme 1. Reactions catalyzed by [Fe]-hydrogenase [13].

Hydrogen is a clean energy carrier and an important chemical reagent. The impressive catalytic activity of hydrogenases has inspired a large body of biomimetic chemistry of hydrogenases $[4,16]$. While many models can catalyze the hydrogen evolution reaction, very few of them can mediate or catalyze the reverse reaction, the hydrogen activation. This article reviews the current state of biomimetic hydrogen activation. Although several reviews on hydrogenases and their models have been published [4-6, 27-31], this topic has not been exclusively covered.

\section{Reactions of [NiFe]-hydrogenase models with hydrogen}

Since the determination of the crystal structure of [NiFe]-hydrogenase, many synthetic models of its active site have been synthesized [4-6, 31,32]. However, only a few models can react with $\mathrm{H}_{2}$.

A Ni thiolate complex [Ni(NHP $\left.\left.{ }^{n} \mathrm{Pr}_{3}\right)\left({ }^{\prime} \mathrm{S}_{3}{ }^{\prime}\right)\right]$ (1a) $\left[{ }^{\prime} \mathrm{S}_{3}{ }^{, 2-}=\right.$ bis(2-sulfanylphenyl)sulfide (2-)] that modeled the nickel core of [NiFe]-hydrogenase reacted slowly with $\mathrm{D}_{2}$ at high pressure, giving $\mathrm{HD}$ and $\left[\mathrm{Ni}\left(\mathrm{NHP}^{n} \mathrm{Pr}_{3}\right)\left({ }^{\prime} \mathrm{S}_{3}\right.\right.$ ')] (1b) (Scheme 2). 1a also catalyzed the $\mathrm{H} / \mathrm{D}$ exchange reaction between $\mathrm{D}_{2} \mathrm{O}$ and $\mathrm{H}_{2}$, a characteristic reaction of [NiFe]-hydrogenase [33].

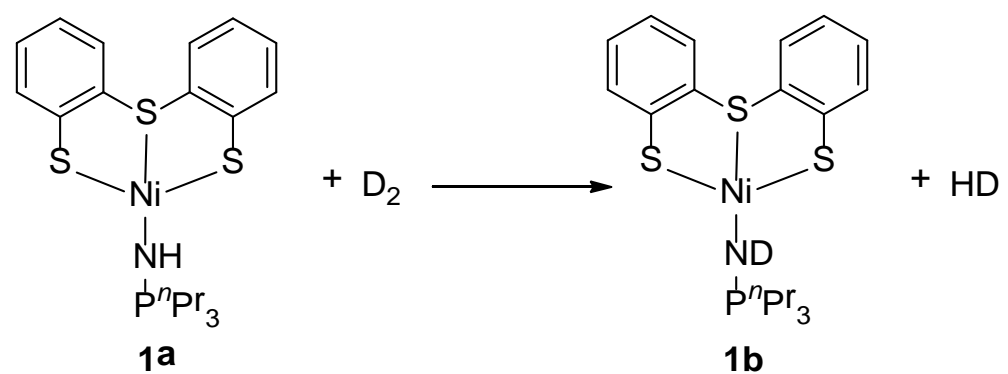

Scheme 2. Reaction of 1a with $\mathrm{D}_{2}$ [33].

The complex [Cp* $\left.\operatorname{Ir}\left(\mathrm{PMe}_{3}\right)(\mathrm{SDmp})\right]\left(\mathrm{BAr}_{4}{ }_{4}\right)(2)(\mathrm{Dmp}=$ 2,6-dimesitylphenyl) [34] reacted with 1 atm of $\mathrm{H}_{2}$ even at $-20{ }^{\circ} \mathrm{C}$, forming a thiol-hydride complex $\left[\mathrm{Cp} * \operatorname{Ir}\left(\mathrm{PMe}_{3}\right)(\mathrm{H})(\mathrm{HSDmp})\right]\left(\mathrm{BAr}_{4}{ }_{4}\right) \quad$ (3). When the temperature was increased to room temperature, complex 3 further reacted with $\mathrm{H}_{2}$ to give complex [Cp*Ir( $\left.\left.\mathrm{PMe}_{3}\right) \mathrm{H}_{3}\right]\left(\mathrm{BAr}_{4}{ }_{4}\right)$ (4) with concomitant release of HSDmp (Scheme 3). 


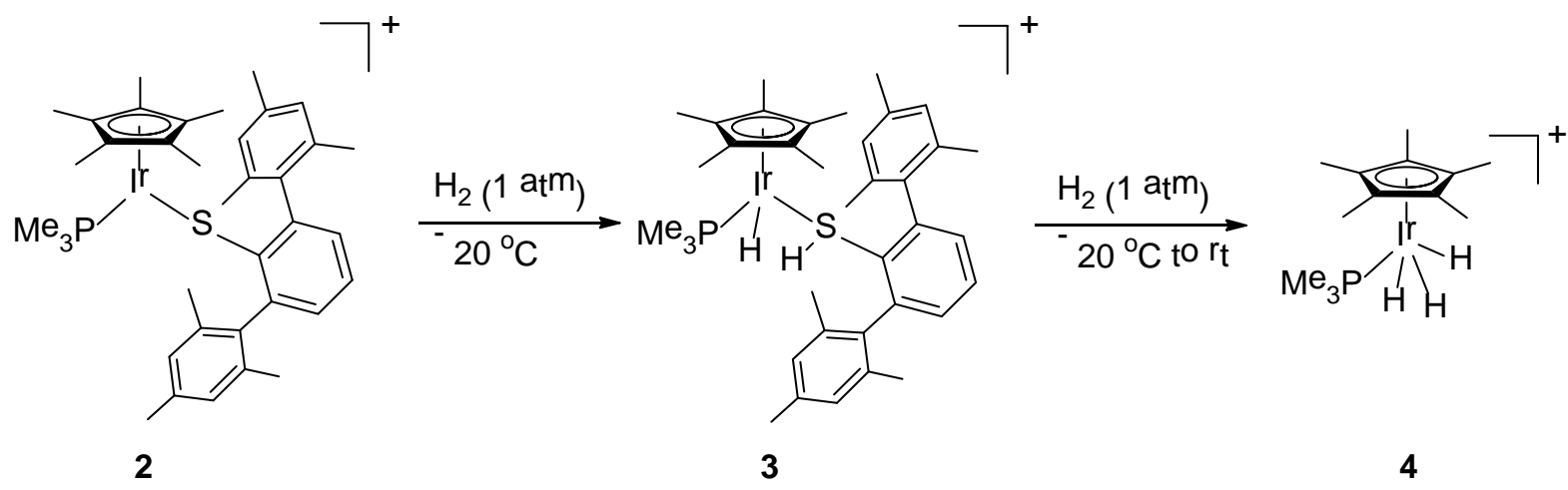

Scheme 3. Reactions of 2 with $\mathrm{H}_{2}$ [34].

Several dinuclear Ru-Ge complexes could heterolytically activate $\mathrm{H}_{2}$ [35-37]. For example, complex [(Dmp)(Dep)Ge( $\mu$-S) $\left.(\mu-\mathrm{O}) \mathrm{Ru}\left(\mathrm{PPh}_{3}\right)\right]$ (5, Dep = 2,6-diethylphenyl) reacted slowly with $\mathrm{H}_{2}$ (10 atm.) at $75^{\circ} \mathrm{C}$ to afford two isomers, anti-6 and syn-6, via $\mathrm{Ru}-\mathrm{O}$ bond cleavage [35]. The proton was accepted by the $\mu$-O ligand, while the $\mathrm{H}^{-}$was accepted by the $\mathrm{Ru}$ ion. Protonation of 5 yielded complex [(Dmp)(Dep) $\left.\mathrm{Ge}(\mu-\mathrm{S})(\mu-\mathrm{OH}) \mathrm{Ru}\left(\mathrm{PPh}_{3}\right)\right]\left(\mathrm{BAr}^{\mathrm{F}}{ }_{4}\right)(7)$ which could split $\mathrm{H}_{2}$ under $1 \mathrm{~atm}$, giving [(Dmp)(Dep) $\left.\mathrm{Ge}(\mu-\mathrm{S})(\mu-\mathrm{H}) \mathrm{Ru}\left(\mathrm{PPh}_{3}\right)\right]\left(\mathrm{BAr}^{\mathrm{F}}{ }_{4}\right)(\mathbf{8})$ and $\mathrm{H}_{2} \mathrm{O}$ (Scheme 4). The reaction of 7 with $\mathrm{H}_{2}$ was reversible: complex 8 reacted with excess $\mathrm{H}_{2} \mathrm{O}$ to give 7 and $\mathrm{H}_{2}$ [36]. Very recently, Matsumoto and co-workers published the theoretical study on this activation of $\mathrm{H}_{2}$ with the Ru-Ge complex [38].
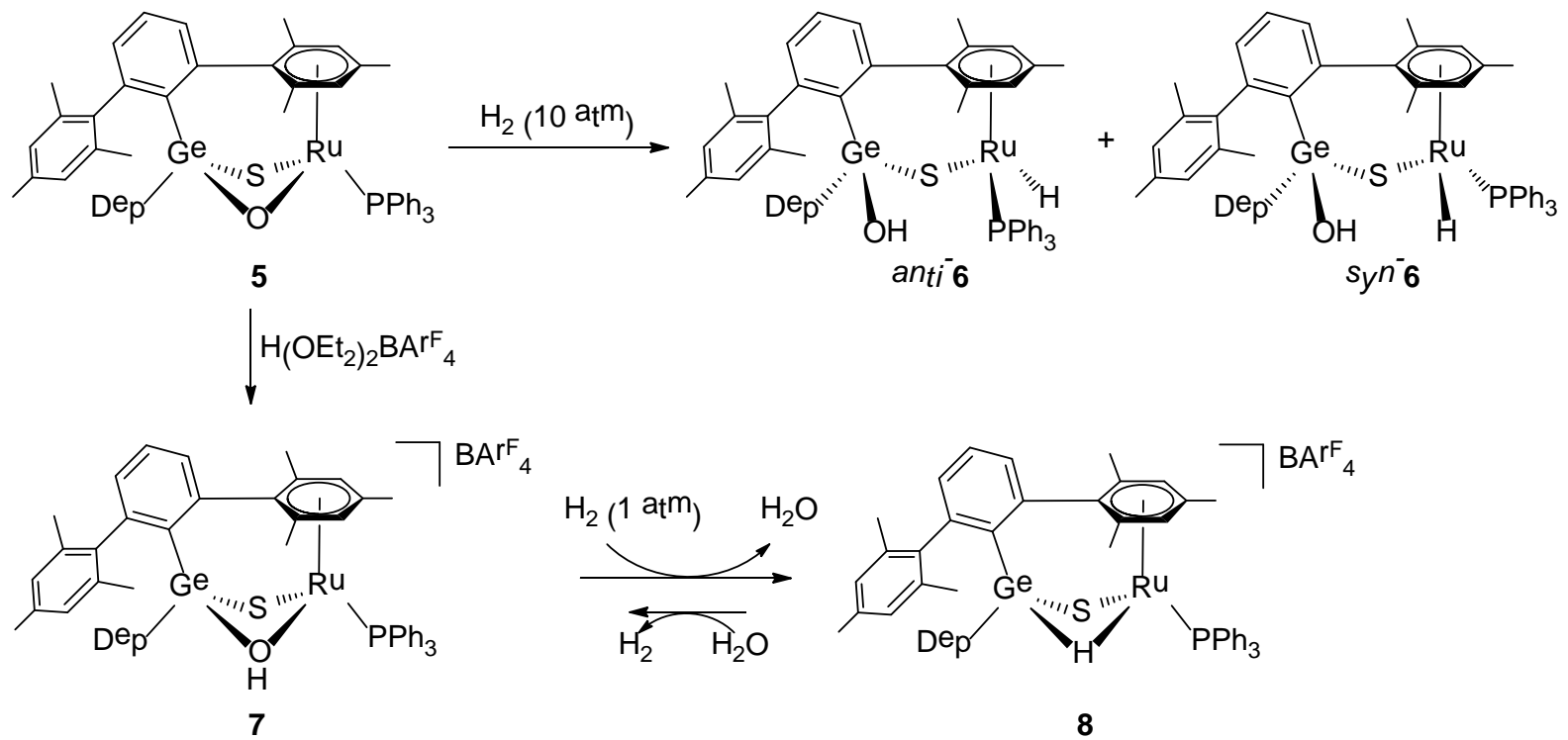

Scheme 4. Reactivity of Ru-Ge complexes [35-37].

Although the above-mentioned complexes exhibit some functions of hydrogenases, none of them contains a ${ }^{10} \mathrm{M}(\mu-\mathrm{S}){ }_{2}{ }^{8} \mathrm{M}$ moiety $\left({ }^{10} \mathrm{M}=\right.$ group 10 metals, ${ }^{8} \mathrm{M}=$ group 8 metals $)$ that is the core of the active site of [NiFe]-hydrogenase. 
The dinuclear Ni-Ru complex $\left[(\mathrm{NiL}) \mathrm{Ru}\left(\mathrm{H}_{2} \mathrm{O}\right)\left(\eta^{6}-\mathrm{C}_{6} \mathrm{Me}_{6}\right)\right]\left(\mathrm{NO}_{3}\right)_{2}\left(\mathbf{9 a}, \mathrm{L}=\mathrm{N}, \mathrm{N}^{\prime}\right.$-dimethyl$\mathrm{N}, \mathrm{N}^{\prime}$-bis(2-mercaptoethyl)-1,3-propanediamine) reacted with $\mathrm{H}_{2}$ in water under ambient conditions, resulting in $\left[(\mathrm{NiL})\left(\mathrm{H}_{2} \mathrm{O}\right)(\mu-\mathrm{H}) \mathrm{Ru}\left(\eta^{6}-\mathrm{C}_{6} \mathrm{Me}_{6}\right)\right]\left(\mathrm{NO}_{3}\right)(\mathbf{1 0 a})$ with a bridging hydride (Scheme 5) [39]. When deprotonated, 10a was transformed into the neutral complex $\left[(\mathrm{NiL})(\mathrm{OH})(\mu-\mathrm{H}) \mathrm{Ru}\left(\eta^{6}-\mathrm{C}_{6} \mathrm{Me}_{6}\right)\right]$ (11a). 11a catalyzed the hydrogenation of aldehydes to the corresponding alcohols in water [40]. When the $\mathrm{C}_{6} \mathrm{Me}_{6}$ group was changed to $\mathrm{C}_{6} \mathrm{Me}_{5} \mathrm{H}$ or $\mathrm{C}_{6} \mathrm{Me}_{4} \mathrm{H}_{2}$, the complexes (9b, 9c) also activated $\mathrm{H}_{2}$. However, if $\mathrm{C}_{6} \mathrm{Me}_{6}$ was replaced by a weaker $\sigma$-donating aromatic group such as $\mathrm{C}_{6} \mathrm{H}_{6}$ or $\mathrm{C}_{6} \mathrm{MeH}_{5}$, the resulting Ni-Ru complexes could no longer split $\mathrm{H}_{2}$. This was attributed to the lower basicity of their coordinated $\mathrm{H}_{2} \mathrm{O}$ ligand [41].

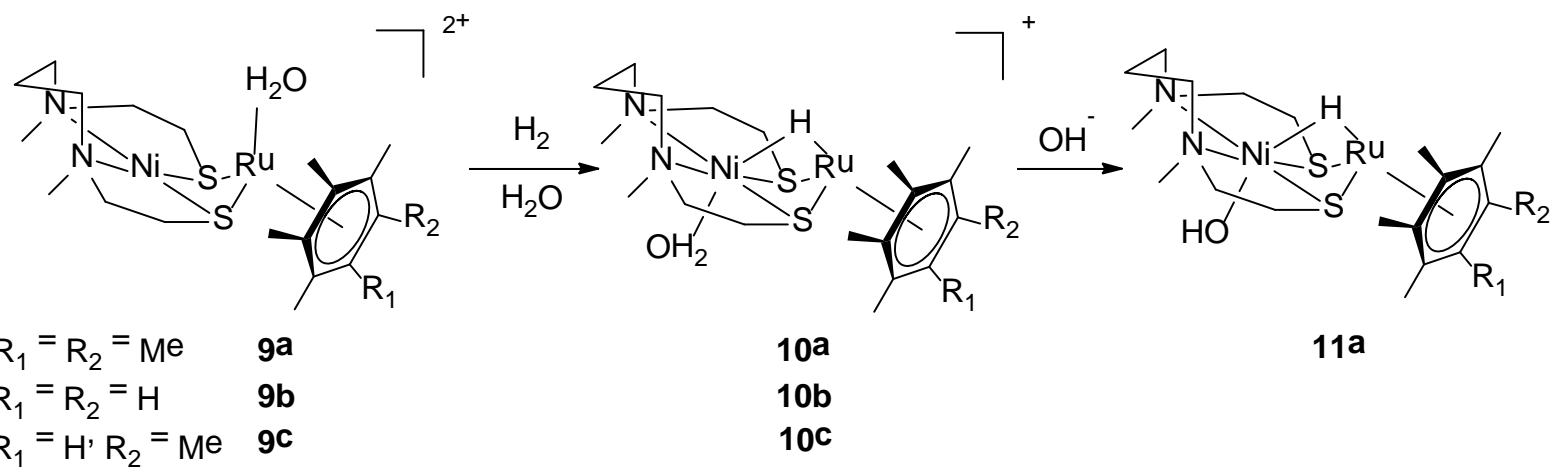

Scheme 5. Reactions of 9 with $\mathrm{H}_{2}$ [39-40].

Catalytic extraction of electrons from $\mathrm{H}_{2}$ was achieved by use of the low-valent $\mathrm{Ni}^{\mathrm{I}} \mathrm{Ru}^{\mathrm{I}}$ complex 12 with $\mathrm{Cu}^{2+}$ as oxidant at $\mathrm{pH}$ 4-6 [42]. A proposed mechanism for the catalytic cycle is shown in Scheme 6, in which $\mathrm{H}_{2}$ is heterolytically activated twice.

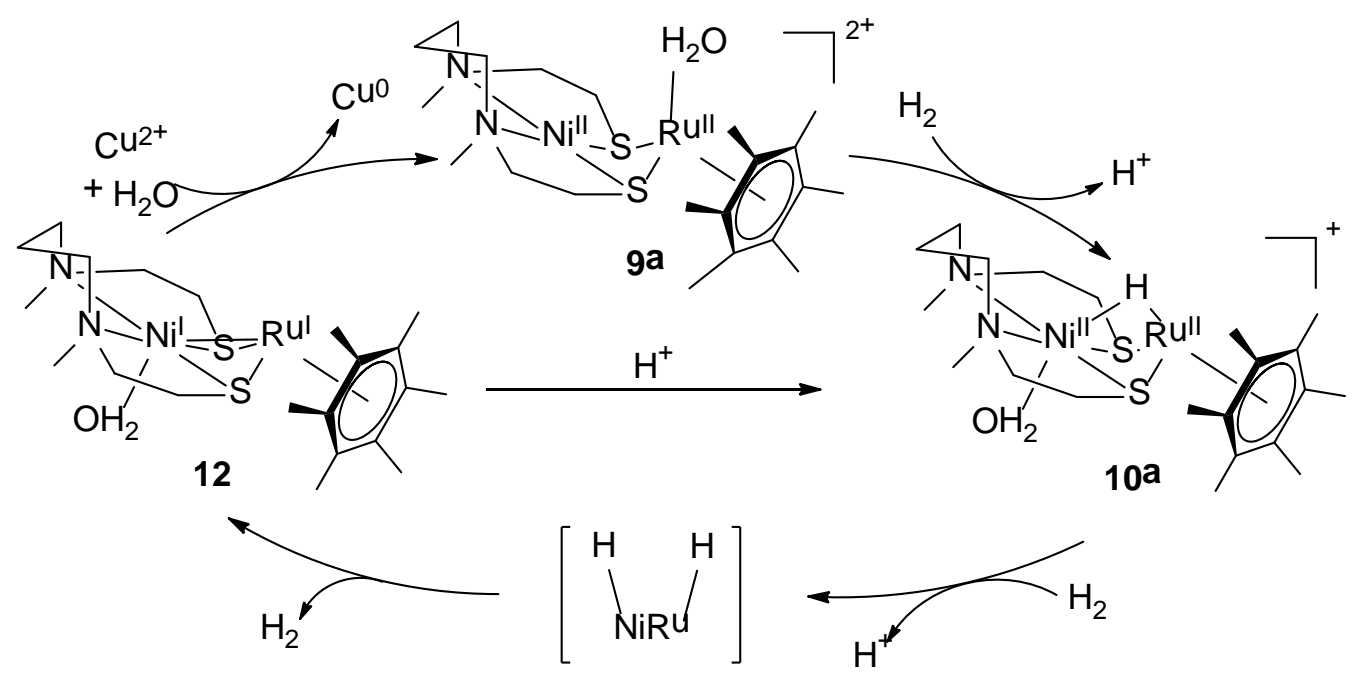

Scheme 6. Reactions of 12 with $\mathrm{H}_{2}$ [42].

A breakthrough was made by the Ogo group when they synthesized complex 
$\left[\mathrm{Ni}(\mathrm{L}) \mathrm{Fe}(\mathrm{MeCN})\left\{\mathrm{P}(\mathrm{OEt})_{3}\right\}_{3}\right]\left(\mathrm{BPh}_{4}\right)_{2}(\mathrm{~L}=\mathrm{N}, \mathrm{N}$-diethyl-3,7-diazanonane-1,9-dithiolato) (13) (Scheme 7) [43]. Compared to 9a-9c, 13 is more similar to the active site of [NiFe]hydrogenase because $\mathrm{Ru}$ is replaced by Fe. The authors introduced three $\mathrm{P}(\mathrm{OEt})_{3}$ groups to replace the aromatic ligands in 9a-9c, which might be the key to its reactivity. $\mathbf{1 3}$ reacted with $\mathrm{H}_{2}$ to give the hydride complex $\left[\mathrm{Ni}(\mathrm{L})(\mu-\mathrm{H}) \mathrm{Fe}\left\{\mathrm{P}(\mathrm{OEt})_{3}\right\}_{3}\right]\left(\mathrm{BPh}_{4}\right)(\mathbf{1 4})$. The reaction required a strong base (NaOMe) to accept the $\mathrm{H}^{+}$from $\mathrm{H}_{2}$. The $\mathrm{H}^{-}$ligand was located on the Fe center. 14 reacted with $\mathrm{H}^{+}$in $\mathrm{CH}_{3} \mathrm{CN}$ to regenerated $\mathbf{1 3}$ and $\mathrm{H}_{2}$. This reaction is sub-stoichiometric. 14 was also able to reduce methyl viologen $\left(\mathrm{MV}^{2+}\right)$ and ferrocenium ion $\left(\left[\mathrm{Fe}\left(\mathrm{C}_{5} \mathrm{H}_{5}\right)_{2}\right]^{+}\right)$to their one-electron reduced forms. This was the first Ni-Fe example that mediated both $\mathrm{H}_{2}$ activation and evolution, an essential feature of [NiFe]-hydrogenase.

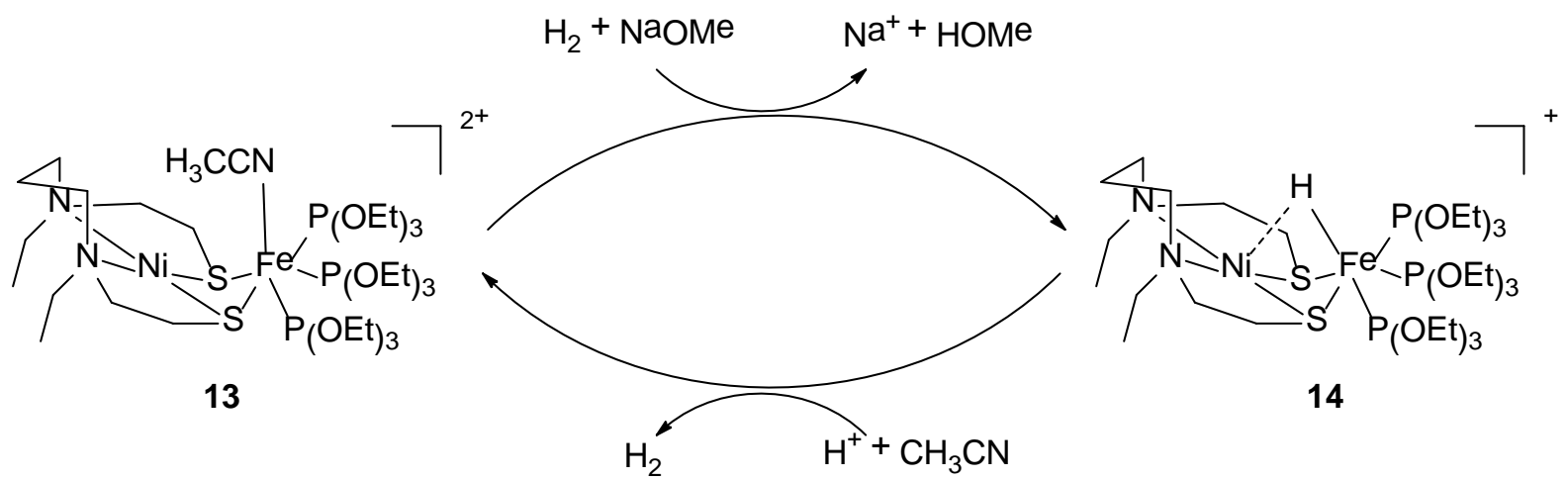

Scheme 7. Reactivity of 13 and 14 [43].

Two Ni-Fe model complexes $(\mathrm{CO})_{2}\left(\mathrm{CNBAr}_{3}\right)_{2} \mathrm{Fe}(\mu$-pdt)Ni(dxpe) (dxpe = dppe, 15a; dxpe = dcpe, 15b) were synthesized by Rauchfuss and co-workers, each with two CO and two $\mathrm{BAr}_{\mathrm{F}}^{3}$ protected cyanide ligands on $\mathrm{Fe}$ (Scheme 8) [44]. Introduction of $\mathrm{BAr}_{3}{ }_{3}$ ligands is essential for $\mathrm{H}_{2}$ activation, because it makes the Fe center more electrophilic. After $\mathrm{H}_{2}$ cleavage, the $\mathrm{H}^{-}$ligand binds to $\mathrm{Fe}$ rather than $\mathrm{Ni}$, giving products $\mathbf{1 6 a}$ and $\mathbf{1 6 \mathbf { b }}$. When a weak acid was added to $\mathbf{1 6}$, dihydrogen-bridging products $\mathbf{1 7 a}$ and $\mathbf{1 7 b}$ were formed, respectively. If a stronger acid such as $\mathrm{HCl}$ was used, $\mathrm{H}_{2}$ was released with concomitant formation of the Cl-adduct 18a and 18b, respectively. 16a was also an electrocatalyst for $\mathrm{H}_{2}$ oxidation in the presence of base DBU. 


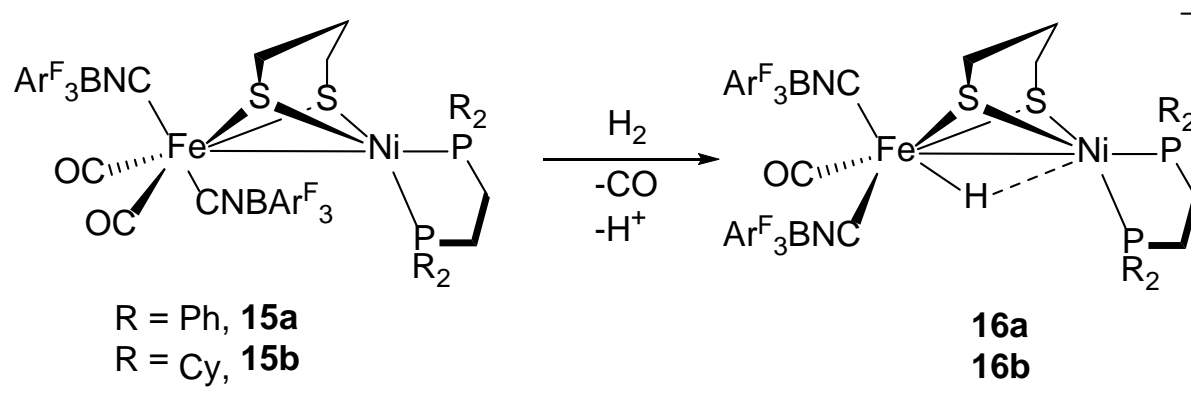

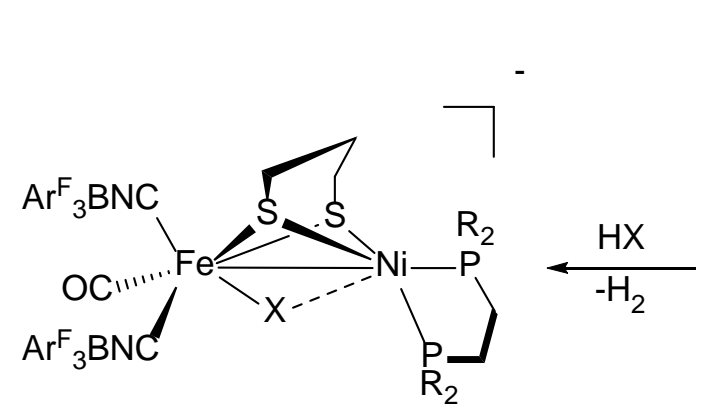

$18 a$

$18 b$

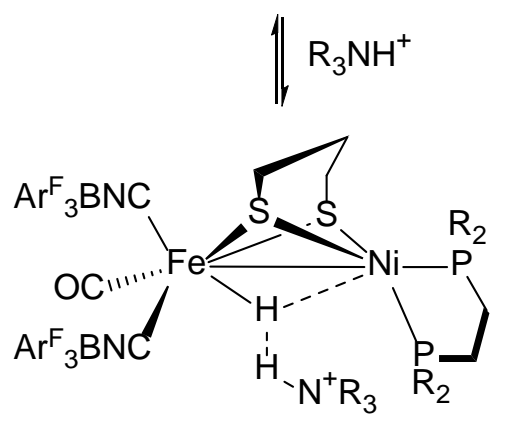

$17 a$

$17 \mathrm{~b}$

Scheme 8. Reactivity of Ni-Fe models of Rauchfuss et al [44].

[(cymene)Ru( $\mu$-pdt)Ni(dppe)](BAr $\left.{ }_{4}\right) \quad$ (19) reacted with 1 atm of $\mathrm{H}_{2}$ to give [(cymene)Ru( $\mu$-pdt) $\left(\mu\right.$-H)Ni(dppe)](BAr $\left.{ }_{4}{ }_{4}\right)$ (20) (Scheme 9) [45]. In this case, $\mathrm{H}_{2}$ was reduced to two $\mathrm{H}^{-}$, while the metal ion was oxidized.

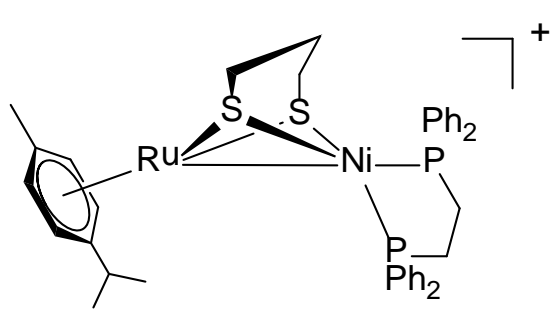

19

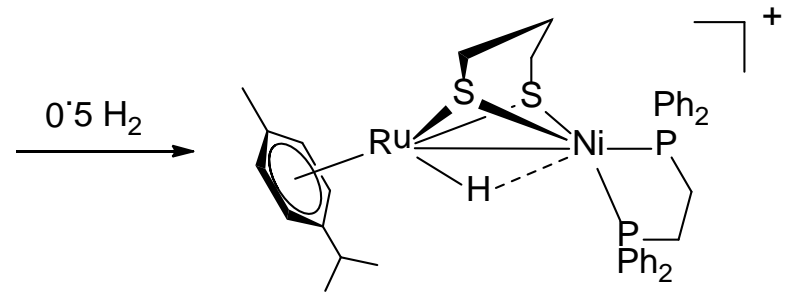

20

Scheme 9. Reaction of 19 with $\mathrm{H}_{2}$ [45].

It should be noted that among all the above complexes, most of them only activate $\mathrm{H}_{2}$ in a stoichiometric or sub-stoichiometric manner. Only a few complexes, such as 1a, 11a, and 12, can activate $\mathrm{H}_{2}$ catalytically. Moreover, nearly all complexes only mediate heterolytic $\mathrm{H}_{2}$ cleavage or $\mathrm{H} / \mathrm{D}$ exchange, but not oxidation of $\mathrm{H}_{2}$ to protons. A notable exception is complex 12.

\section{Reactions of [FeFe]-hydrogenase models with hydrogen}


While the structure of the active site of [FeFe]-hydrogenase was first revealed at the late 1990s [46,47], a primitive structural model, dithiolate-bridged hexacarbonyl diiron complexe [( $\mu$-SEt $\left.)_{2} \mathrm{Fe}_{2}(\mathrm{CO})_{6}\right]$, was reported already in 1929 [48]. Modern models contain additional cyanide, phosphine or carbene ligands. Many models mediate or catalyze proton reduction to form $\mathrm{H}_{2}$, however, only a few models can split or oxidize hydrogen.

\subsection{Diiron models without an internal amine moiety}

Treatment of the bridged dithiolato complex ( $\mu$-pdt) $\left[\mathrm{Fe}(\mathrm{CO})_{2}\left(\mathrm{PMe}_{3}\right)_{2}\right]_{2} \quad$ (21, pdt $=\mathrm{SCH}_{2} \mathrm{CH}_{2} \mathrm{CH}_{2} \mathrm{~S}$ ) with concentrated $\mathrm{HCl}$ yielded a stable bridging hydride complex 22 (Scheme 10) [49]. Complex 22 mediated H/D exchange from $\mathrm{H}_{2} / \mathrm{D}_{2}$ and from $\mathrm{H}_{2} / \mathrm{D}_{2} \mathrm{O}$. The exchange reactions were promoted by sunlight and were inhibited by $\mathrm{CO}$. This suggests that an open site for $\mathrm{D}_{2}$ binding prior to $\mathrm{D}$-D cleavage was a key step in the reactions.

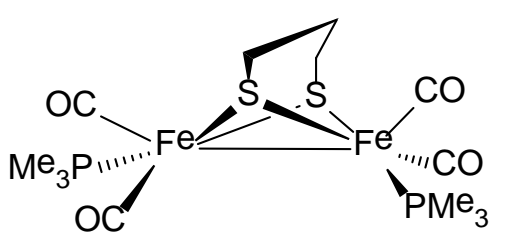

21

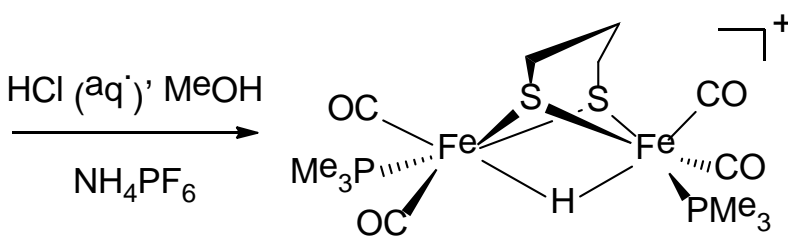

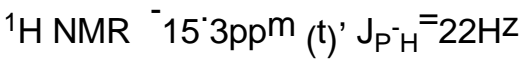

Scheme 10. Synthesis of complex 22 [49].

A series of similar complexes, $(\mu-\mathrm{R})_{2}\left[\mathrm{Fe}(\mathrm{CO})_{2}\left(\mathrm{PMe}_{3}\right)\right]_{2}, \quad\left(\mathrm{R}=\mathrm{SEt}, \mathrm{SCH}_{2} \mathrm{CH}_{2} \mathrm{~S}\right.$, $\mathrm{SCH}_{2} \mathrm{C}_{6} \mathrm{H}_{4} \mathrm{CH}_{2} \mathrm{~S}$ ) and their protonated derivatives were studied by Darensbourg and coworkers [50]. The different thiolate ligands had no effects on H/D exchange. Therefore, the sulfur ligands are unlikely proton acceptors in $\mathrm{H}_{2}$ cleavage. Instead, these ligands are present due to bioavailability. Meanwhile, two mechanisms were proposed for the H/D exchange on 22 (Scheme 11).

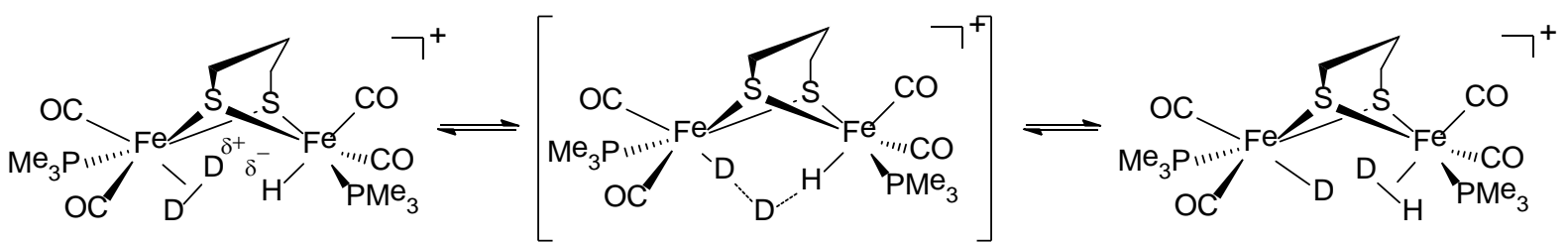




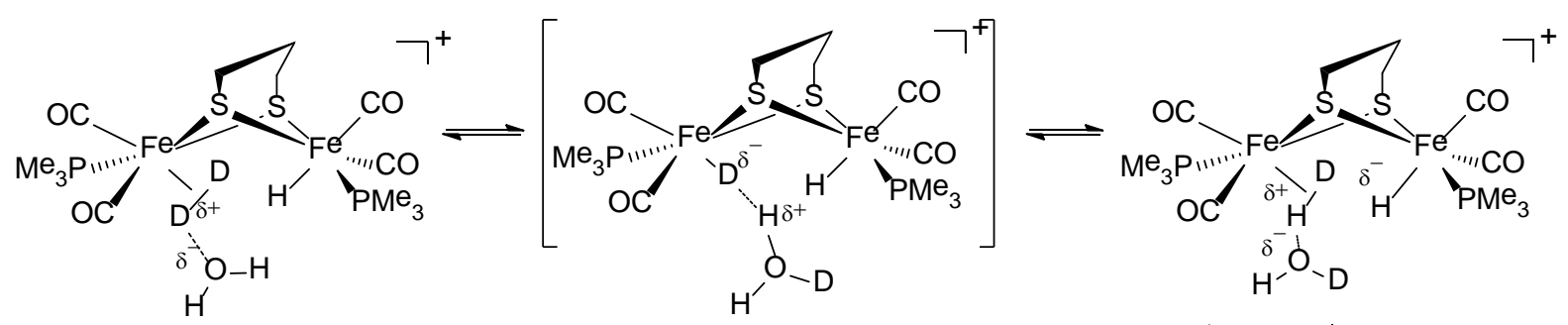

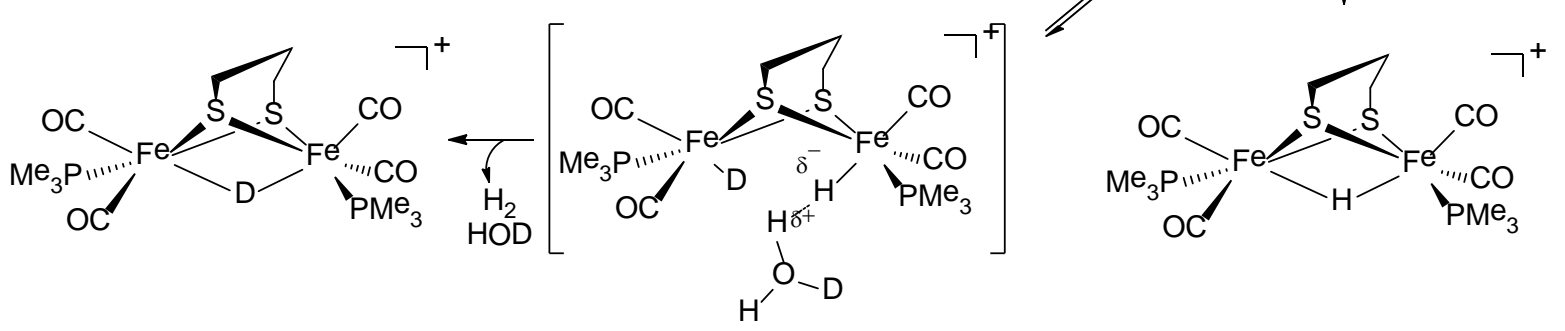

Scheme 11. The two proposed pathways of H/D exchange by 22 [50].

Model complex 23 was obtained from reaction of 21 and $\mathrm{SMe}^{+}$(Scheme 12) [51]. This complex can take up $\mathrm{H}_{2}$ and catalyze the photolytic $\mathrm{H} / \mathrm{D}$ exchange in $\mathrm{D}_{2} / \mathrm{H}_{2} \mathrm{O}$. It does not catalyze $\mathrm{H}_{2} / \mathrm{D}_{2}$ exchange under anhydrous conditions.

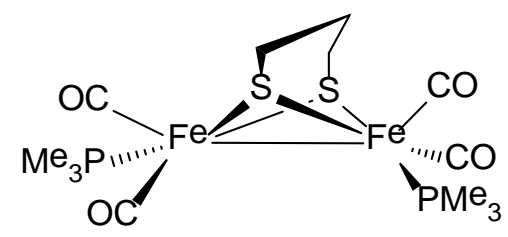

21

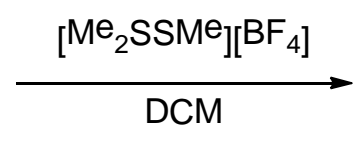

Scheme 12. Synthesis of complex 23 [51].

A proposed mechanism for the H/D exchange is shown in Scheme 13. The $\mathrm{H}_{2} / \mathrm{D}_{2}$ binding site is trans to the $\mu$-SMe. $\mathrm{H}_{2} \mathrm{O}$ is the external base to facilitate $\mathrm{H} / \mathrm{D}$ exchange.<smiles></smiles>
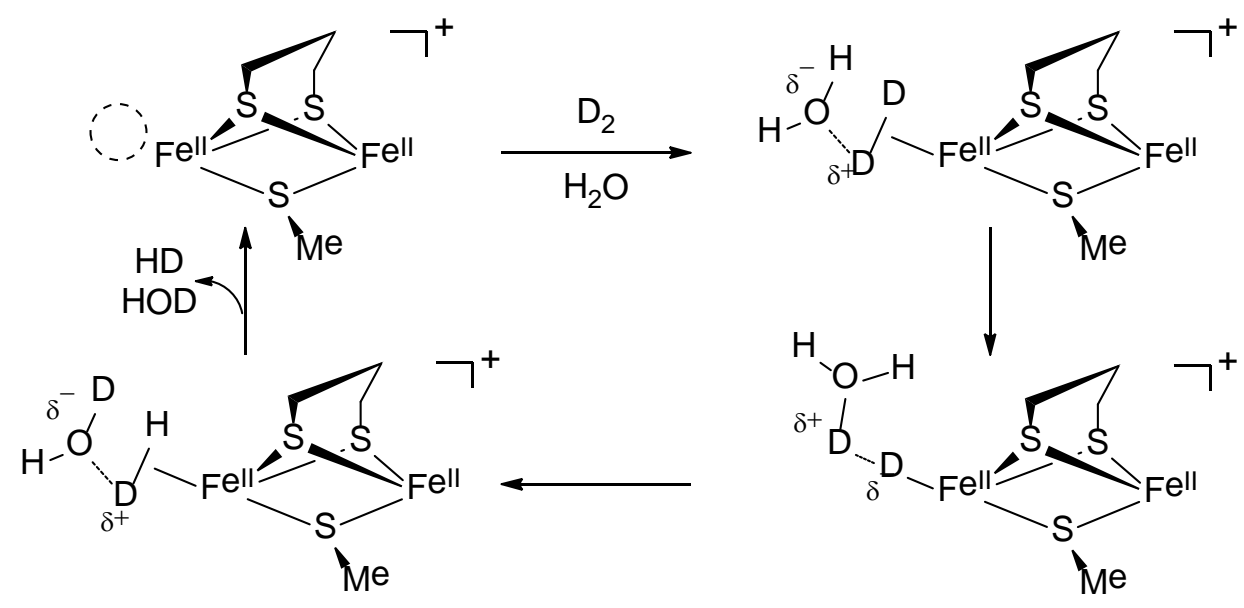

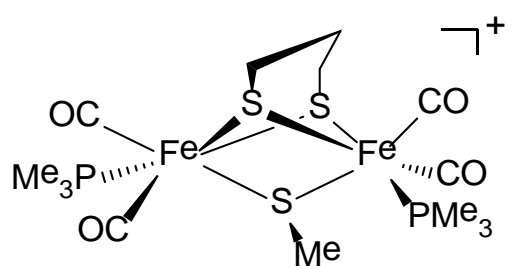

23

Scheme 13. The proposed mechanism for H/D exchange by 23 [51]. 
Oxidative addition of dihydrogen and silane on a [FeFe]-hydrogenase model 24 (dppv = 1,2-bis(diphenylphosphino)ethylene, dppbz = 1,2-bis(diphenylphosphino)benzene ) [52] was reported. Reaction of $\mathbf{2 4}$ with $\mathrm{H}_{2}$ under light gave 25. Analogous reaction with $\mathrm{Ph}_{2} \mathrm{SiH}_{2}$ gave 26. It was proposed that the reactions proceeded by decarbonylation under light followed by formation of a transient $\sigma$ complex before intramolecular oxidative addition. Photolysis of 26 gave complex 27 (Scheme 14).

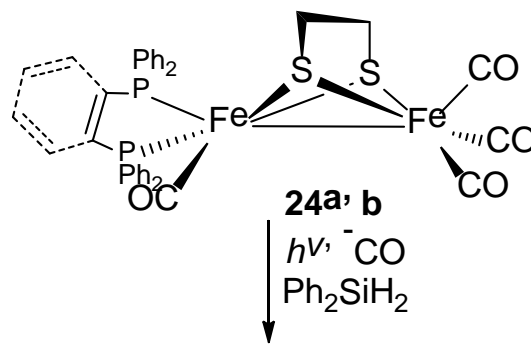
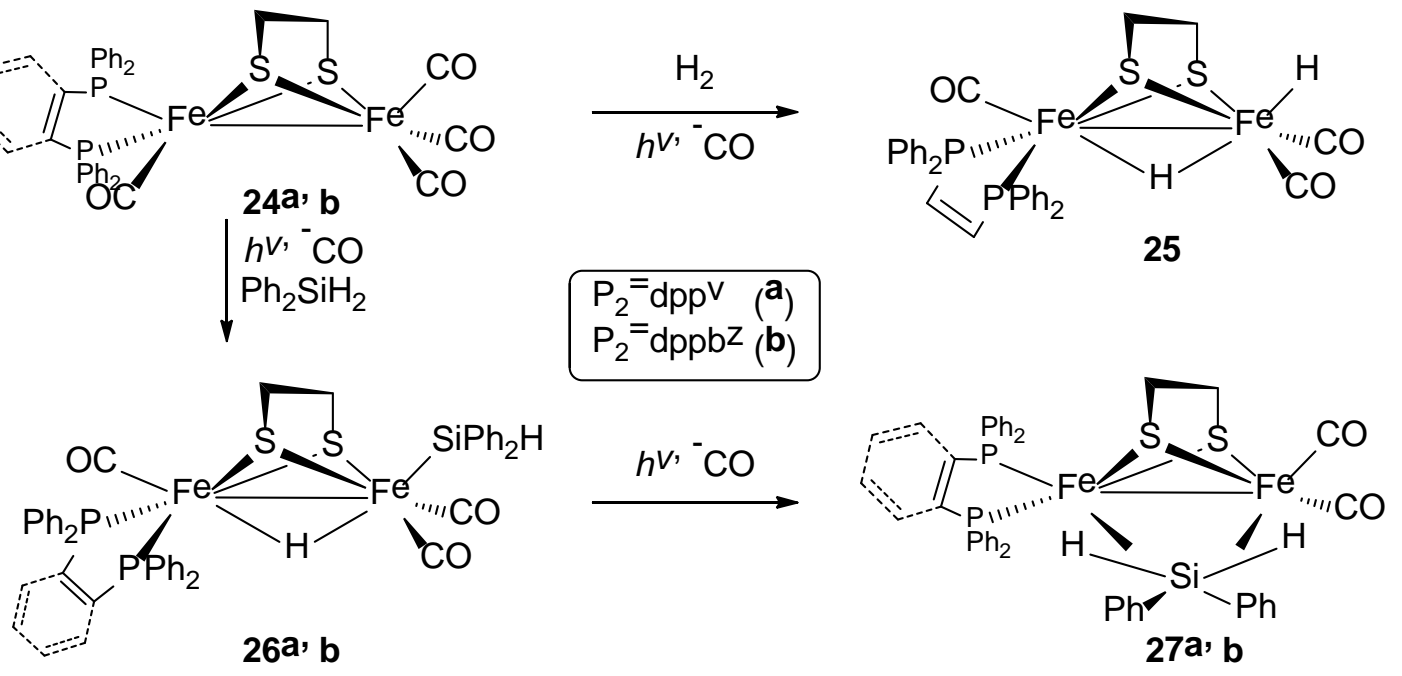

Scheme 14. Reaction of 24 with $\mathrm{H}_{2}$ and $\mathrm{Ph}_{2} \mathrm{SiH}_{2}$ [52].

Heating of complex 29, obtained by oxidation of complex 28 with $\left[\mathrm{N}\left(\mathrm{Ar}^{2,4-\mathrm{Br}}\right)_{3}\right]\left[\mathrm{SbCl}_{6}\right]$ and anion metathesis with $\mathrm{Li}\left[\mathrm{B}\left(\mathrm{C}_{6} \mathrm{~F}_{5}\right)_{4}\right]$, in fluorobenzene to $70^{\circ} \mathrm{C}$ under 1 atm of hydrogen gas resulted in the cationic bridging hydride complex $\left[\mathrm{Fe}_{2}(\mu-\mathrm{H})\left(\mu-\mathrm{S}_{2} \mathrm{C}_{3} \mathrm{H}_{6}\right)(\mathrm{CO})_{6}\right]\left[\mathrm{B}\left(\mathrm{C}_{6} \mathrm{~F}_{5}\right)_{4}\right](30)$, albeit in a small yield (ca. 5\%) (Scheme 15) [53,54].

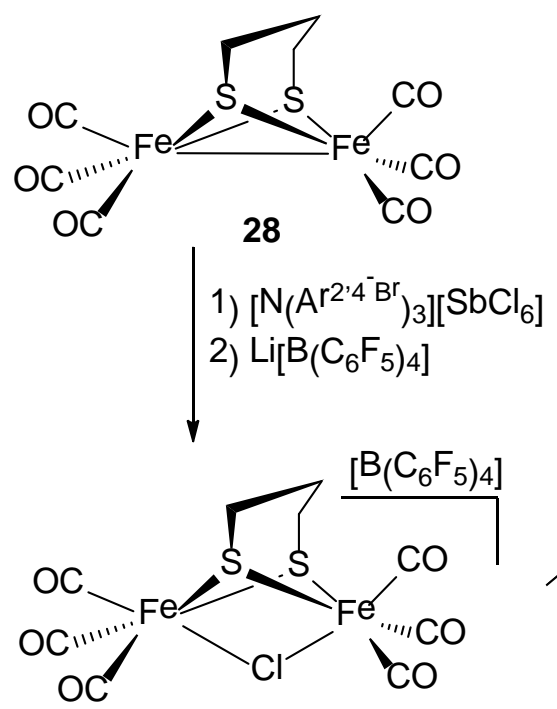

29

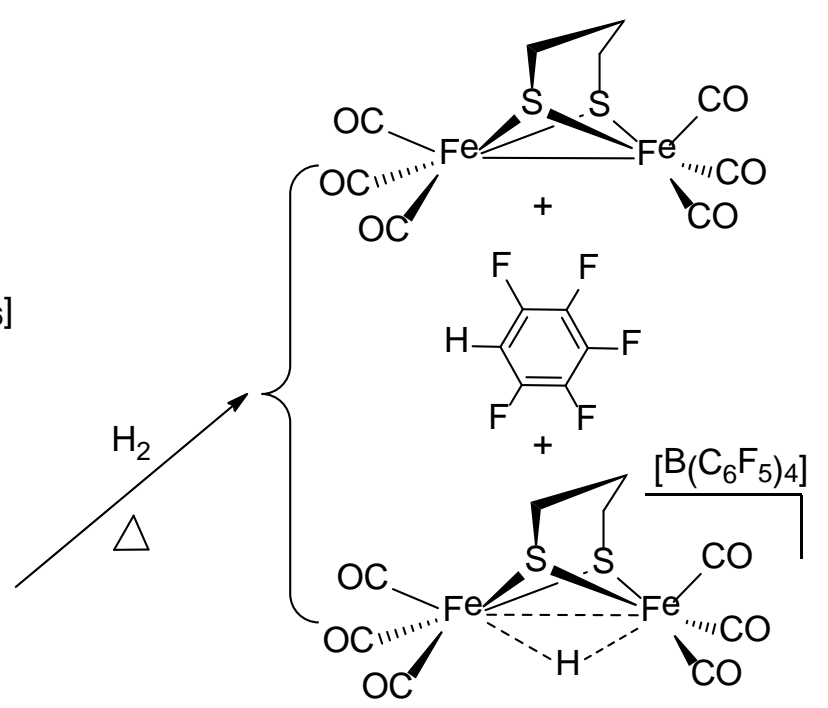

30

Scheme 15. Reaction of 29 with $\mathrm{H}_{2}$ [53-54]. 
Among these diiron model complexes without an internal amine moiety, complexes 22 and 23 can catalytically cleavage $\mathrm{H}_{2}$, while complexes 24 and 29 can only react with $\mathrm{H}_{2}$ in a stoichiometric manner. None of these models are reported to oxidize $\mathrm{H}_{2}$ into protons.

\subsection{Diiron complexes with an internal amine moiety}

[FeFe]-hydrogenase has an active site made of a diiron core bridged by a 2-aza-propane1,3-dithilate ligand. The internal amine nitrogen of the 2-aza-propane-1,3-dithilate ligand is an important proton acceptor for heterolytic cleavage of $\mathrm{H}_{2}$ [55]. Thus, many model complexes containing an internal amine moiety have been developed.

The complexes with an azadithiolate ligand $\left[\mathrm{Fe}_{2}\left[\left(\mathrm{SCH}_{2}\right)_{2} \mathrm{X}\right)(\mathrm{CO})_{3}(\mathrm{PMe})_{3}(\mathrm{dppv})\right]^{+}(\mathbf{3 1 b}, \mathbf{c})$ could react with $\mathrm{H}_{2}$, in a stoichiometric manner, to give the corresponding hydride complexes 32b,c. The related complexes with a propanedithiolate ligand $\left[\mathrm{Fe}_{2}\left[\left(\mathrm{SCH}_{2}\right)_{2} \mathrm{CH}_{2}\right)(\mathrm{CO})_{3}(\mathrm{PMe})_{3}(\mathrm{dppv})\right]^{+}$(31a) or an oxadithiolate ligand $\left[\mathrm{Fe}_{2}\left[\left(\mathrm{SCH}_{2}\right)_{2} \mathrm{O}\right)(\mathrm{CO})_{3}(\mathrm{PMe})_{3}(\mathrm{dppv})\right]^{+}$(31d), on the other hand, were unreactive toward $\mathrm{H}_{2}$ (Scheme 16) [56,57]. These results suggest that heterolytic hydrogen activation was assisted by the azadithiolate ligand.

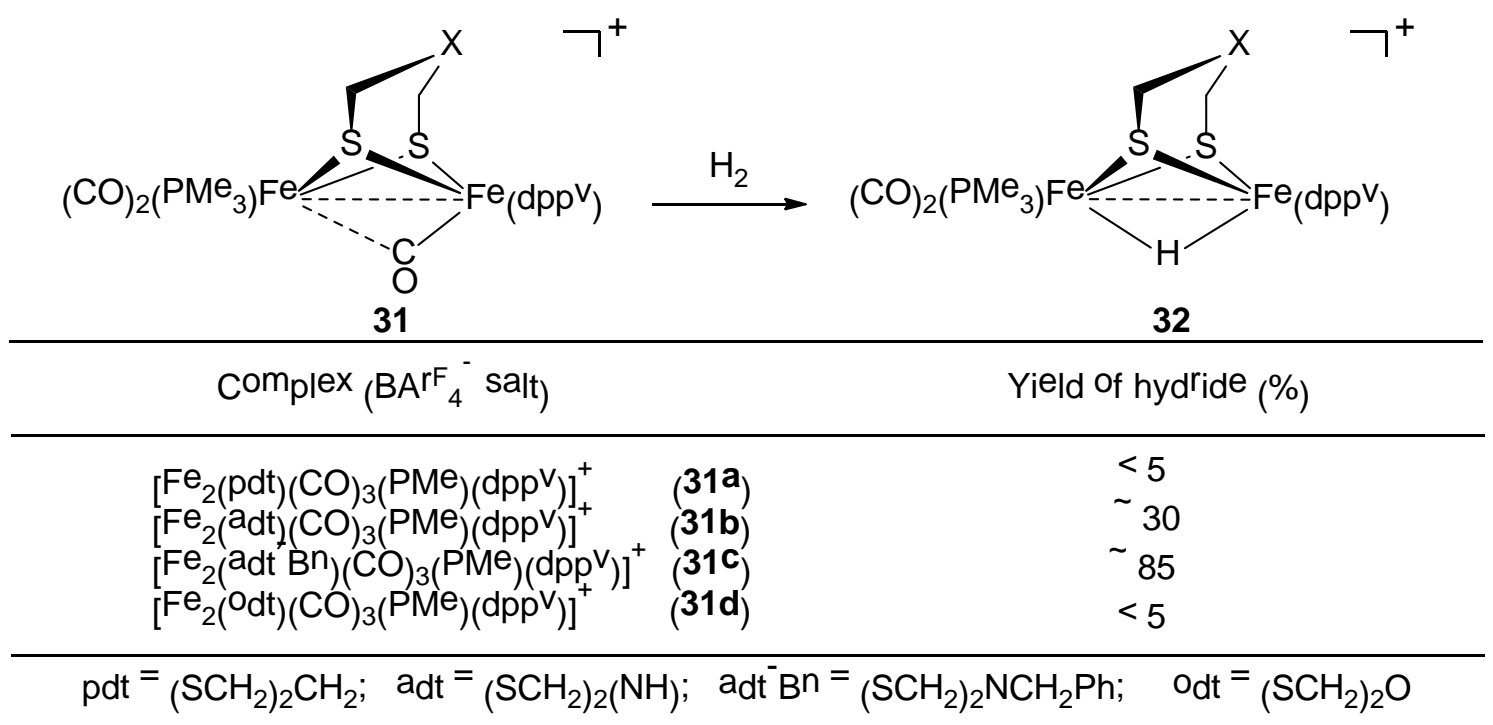

Scheme 16. Reactions of 31 with $\mathrm{H}_{2}$ [56-57].

Complex $\left[\mathrm{Fe}_{2}\left[\left(\mathrm{SCH}_{2}\right)_{2} \mathrm{NBn}\right](\mathrm{CO})_{3}(\mathrm{dppv})\left(\mathrm{PMe}_{3}\right)\right]^{+}$(31c) reacted with $\mathrm{H}_{2}$ only slowly $(>26 \mathrm{~h}$, $25^{\circ} \mathrm{C}, 1800 \mathrm{psi} \mathrm{H}_{2}$ ). In the presence of 1 equiv. of a mild oxidant, $\left[\mathrm{Fe}\left(\mathrm{C}_{5} \mathrm{Me}_{5}\right)_{2}\right] \mathrm{BAr}_{4}{ }_{4}\left[\mathrm{Ar}^{\mathrm{F}}=3.5-\mathrm{C}_{6} \mathrm{H}_{3}\left(\mathrm{CF}_{3}\right)_{2}\right]\left([\mathrm{Fc}] \mathrm{BAr}^{\mathrm{F}}{ }_{4}\right)$, however, 31c reacted with 2 atm $\mathrm{H}_{2}$ at $25^{\circ} \mathrm{C}$ to give the diferrous hydride product 33 quantitatively in several hours (Scheme 17) [58]. In the presence of 1 equiv. of $\left[\mathrm{Fc}_{\mathrm{BAAr}}{ }_{4}\right.$, the more electrophilic diiron model $\left[\mathrm{Fe}_{2}\left[\left(\mathrm{SCH}_{2}\right)_{2} \mathrm{NBn}\right](\mathrm{CO})_{4}(\mathrm{dppn})\right]^{+} \quad$ (34) (dppn $=$ 1,8-bis(diphenylphosphino)naphthalene) reacted with $1 \mathrm{~atm} \mathrm{H}_{2}$ even more rapidly $\left(\mathrm{t}_{1 / 2}<13 \mathrm{~min}\right.$ at $\left.20^{\circ} \mathrm{C}\right) . \mathrm{H}_{2}$ activation by [34]/[FC] ${ }^{+}$is 10 -fold faster than that by $[31 \mathrm{c}] /[\mathrm{Fc}]^{+}$and $10^{4}$-fold faster than that by complex 31c in the absence of an oxidant. Kinetic study indicates that $\mathrm{H}_{2}$ binding is the rate-determining step in these reactions. 


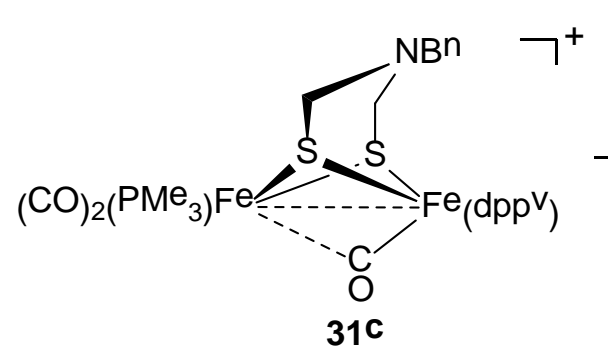
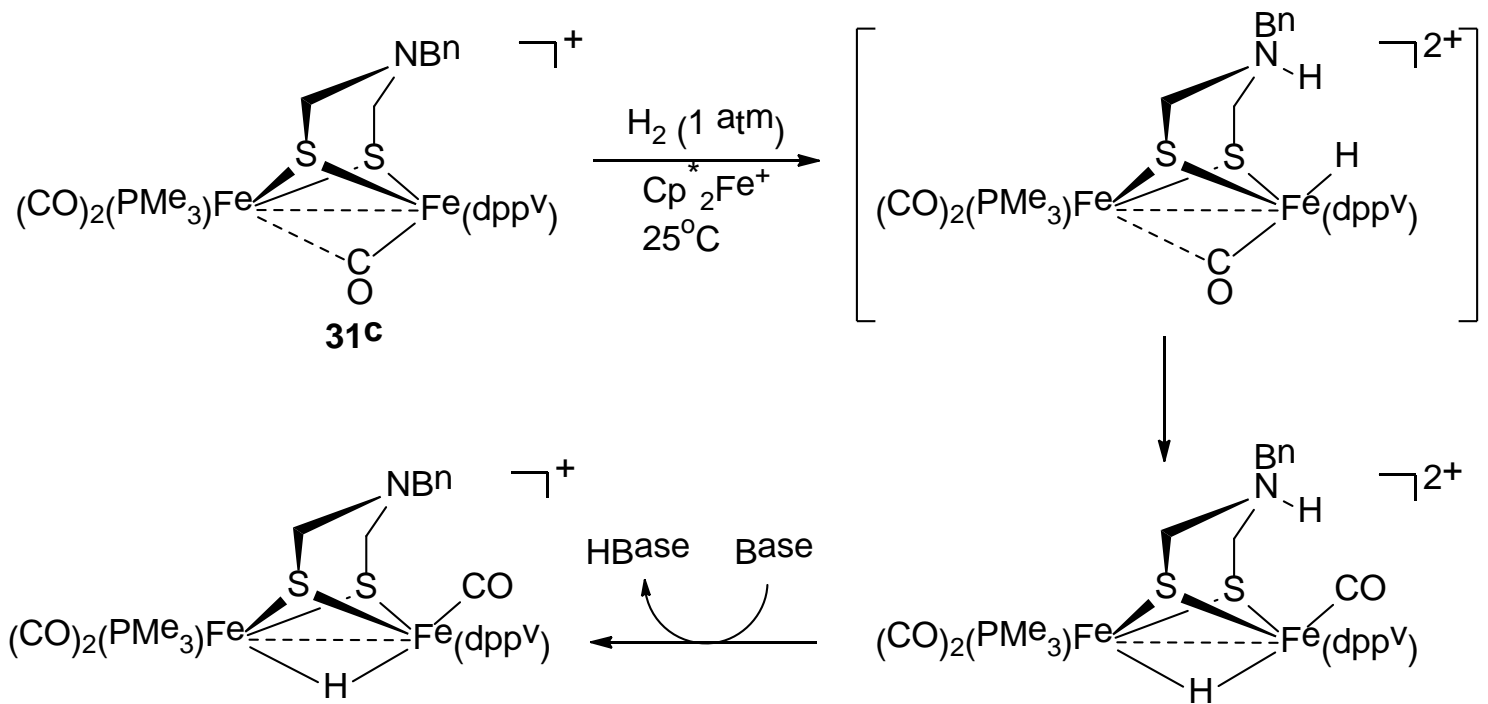

33

Scheme 17. Reaction of 31c with $\mathrm{H}_{2}$ in the presence of [FC]BAr ${ }_{4}{ }_{4}[58]$.

Rauchfuss and co-worker introduced a redox active $\mathrm{FcP}^{*}$ ligand to complex $\left[\mathrm{Fe}_{2}\left[\left(\mathrm{SCH}_{2}\right)_{2} \mathrm{NBn}\right](\mathrm{CO})_{4}(\mathrm{dppv})\right]^{+}(35)$ as a model of the Fe-S cluster found in the active site of [FeFe]-hydrogenase. The dicationic complex $36^{2+}$ reacted with $\mathrm{H}_{2}$ through proton-coupled electron transfer to give the bridging hydride complex 37 [59]. The FcP* ligand was reduced by one electron and a heterolytic $\mathrm{H}_{2}$ cleavage pathway was proposed (Scheme 18). Whereas 31c can only stoichiometrically activate $\mathrm{H}_{2}$, the dication $36^{2+}$ could act as a catalyst for the oxidation of $\mathrm{H}_{2}$ in the presence of excess oxidant and excess base, although the rate is only 0.4 turnover/h. 


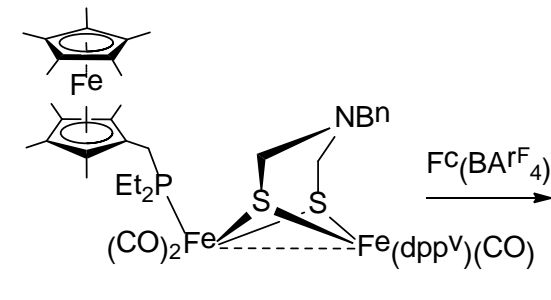

36

$F e_{(I)} F e_{(l)} F e_{(l)}$

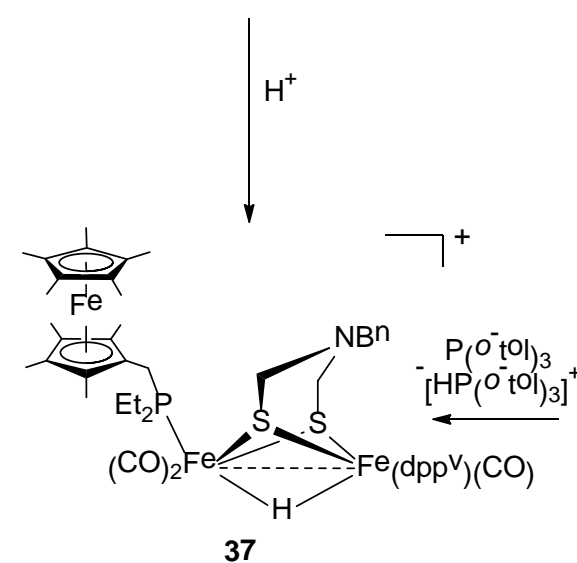

$F e_{(I I)} F e_{(I I)} F e_{(I I)}$

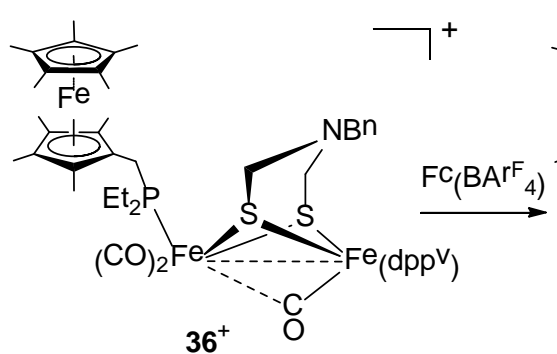

$F e_{(I)} F e_{(I)} F e_{(l)}$
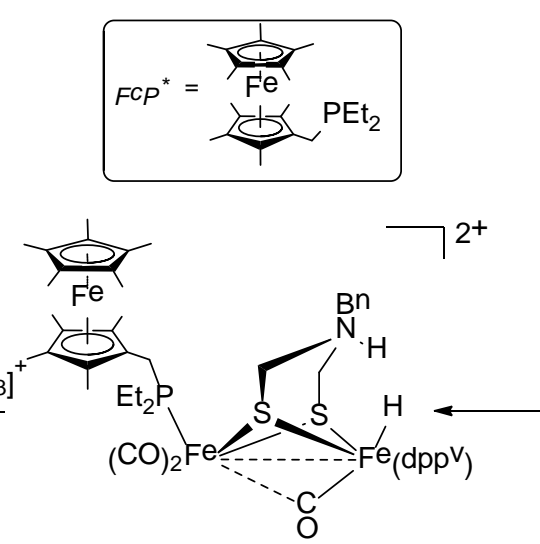

$F e_{(I)} F e_{(I I)} F e_{(I I)}$

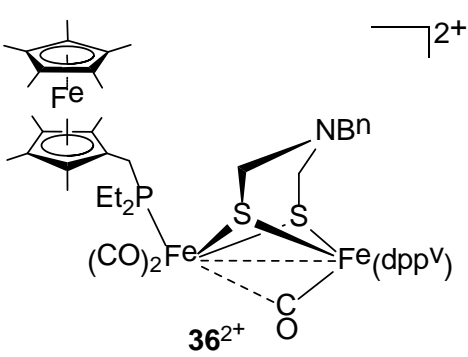

$F^{e}(I I I) F^{e}(I I) F e(l)$
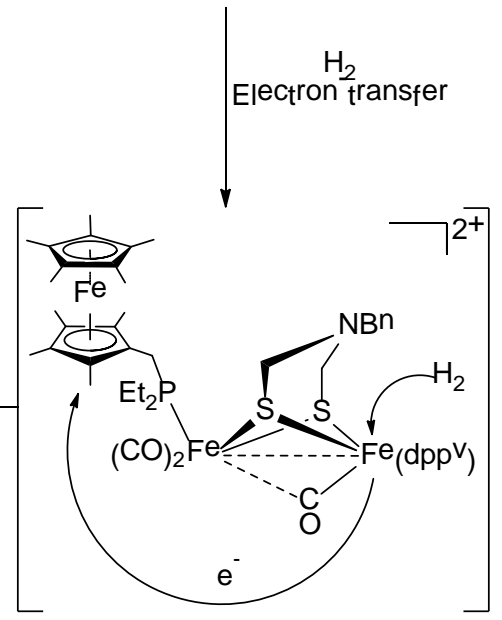

Scheme 18. Model complexes with the redox-active ligand $\mathrm{FcP}^{*}$ and the reaction of $36^{2+}$ with $\mathrm{H}_{2}$ [59].

The complex [( $\mu$-pdt $)\left\{\mathrm{Fe}(\mathrm{CO})_{3}\right\}\left\{\mathrm{Fe}(\mathrm{CO})\left(\kappa_{2}-\mathrm{Ph}_{2} \mathrm{PCH}_{2} \mathrm{~N}\left({ }^{n} \mathrm{Pr}\right) \mathrm{CH}_{2} \mathrm{PPh}_{2}\right\}\right](38)[60,61]$ could catalytically oxidize $\mathrm{H}_{2}$ using excess $\mathrm{FcBAr}_{4}{ }_{4}$ as oxidant and $\mathrm{P}(o \text {-totyl })_{3}$ as base [62]. Analogous complex $\left[(\mu-p d t)\left\{\mathrm{Fe}(\mathrm{CO})_{3}\right\}\{\mathrm{Fe}(\mathrm{CO})(\mathrm{dppp}\}]\right.$ (39) lacking an internal base on the phosphine ligand didn't react with 1 atm $\mathrm{H}_{2}$ under similar conditions. A proposed mechanism for $\mathrm{H}_{2}$ oxidation is shown in Scheme 19. It was noted that the catalytic activity of complex $\mathbf{3 8}$ for $\mathrm{H}_{2}$ oxidation was unchanged in the presence of $2 \% \mathrm{CO}$. 


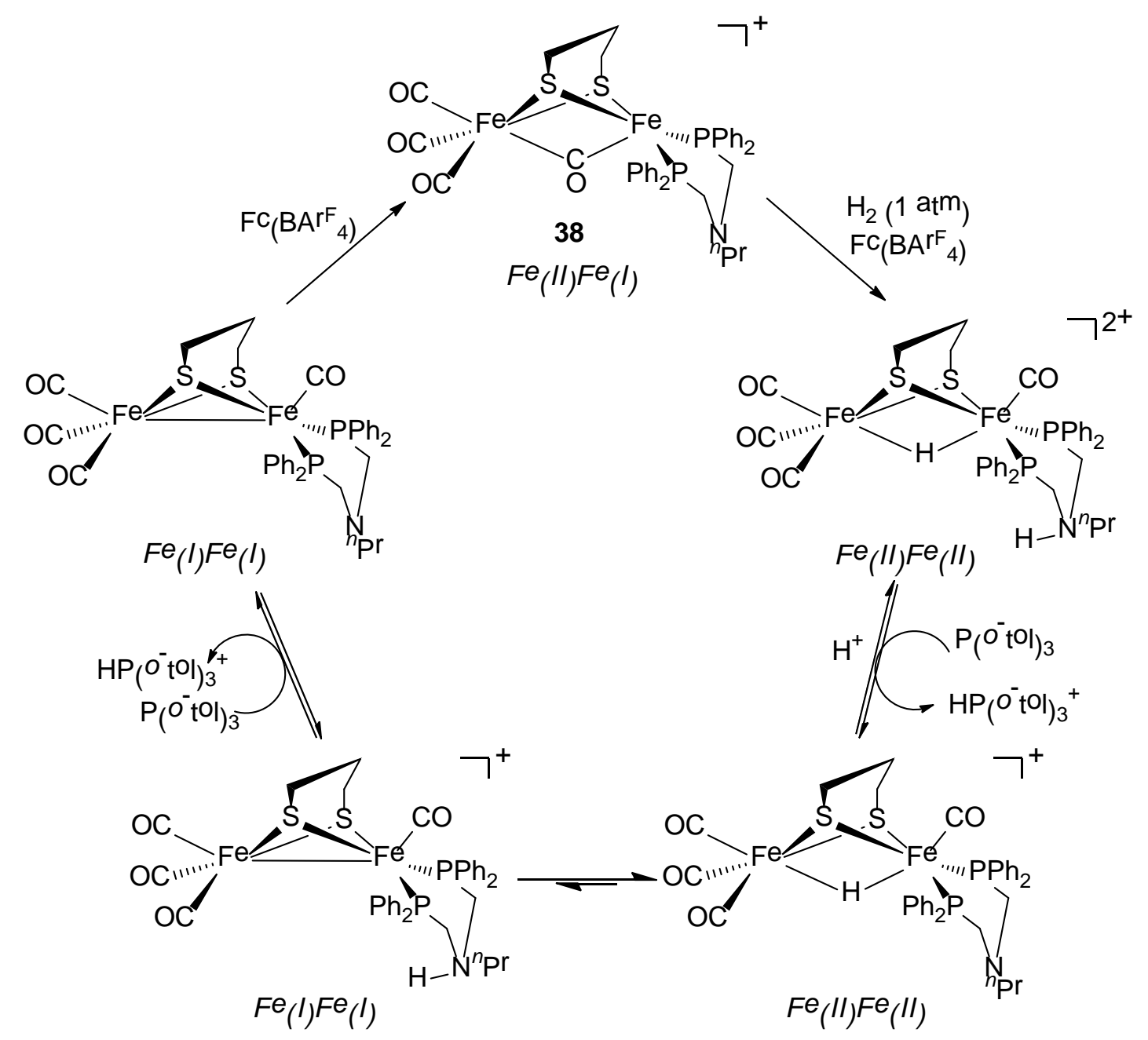

Scheme 19. Proposed mechanism for $\mathrm{H}_{2}$ oxidation catalyzed by complex 38 [62].

\subsection{Bio-inspired complexes with an internal amine moiety}

Inspired by the pendant $\mathrm{SCH}_{2} \mathrm{NHCH}_{2} \mathrm{~S}$ ligand in the active site of [FeFe]-hydrogenase, DuBois, Bullock, and co-workers developed a series of functional models of bis-diphosphine nickel complexes with pendant amines that are active for either/both $\mathrm{H}_{2}$ production or/and $\mathrm{H}_{2}$ oxidation. [63-65] For example, $\mathrm{Ni}(\mathrm{II})$ complex $\left[\mathrm{Ni}\left(\mathrm{P}^{\mathrm{Ph}}{ }_{2} \mathrm{~N}_{2}{ }_{2}\right)\right]^{2+}\left(\mathrm{R}=\mathrm{CH}_{2} \mathrm{CH}_{2} \mathrm{OMe}\right)$ (40) reacted with $\mathrm{H}_{2}(1 \mathrm{~atm})$ to form a mixture of $\mathrm{Ni}(0)$ isomers 41a, 41b and 41c, with two protonated amines (Scheme 20) [66]. Moreover, 40 could electrocatalytically produce and oxidize $\mathrm{H}_{2}$ close to the thermodynamic potential. A similar complex $\left[\mathrm{Ni}\left(\mathrm{P}^{\mathrm{Cy}}{ }_{2} \mathrm{~N}^{\mathrm{Gly}}{ }_{2}\right)\right]$ exhibited similar functions even in water [67]. 


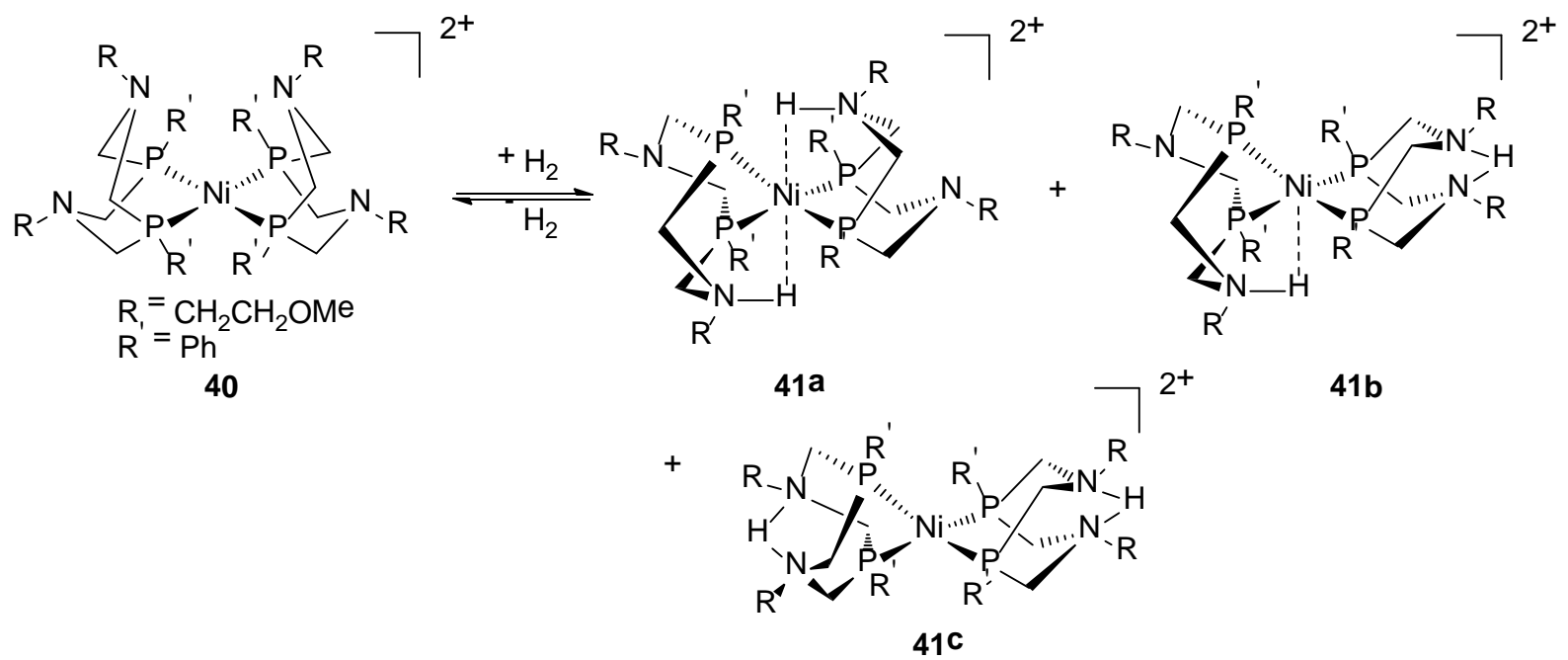

Scheme 20. Reaction of $\mathbf{4 0}$ with $\mathrm{H}_{2}$ [66].

Along the same line, DuBois et al. synthesized several Fe(II) complexes based on similar pendant amines in the diphosphine ligands (Scheme 21) [68-70]. Complex $\left[\left(\mathrm{CpC}_{6} \mathrm{~F}_{5}\right) \mathrm{Fe}\left(\mathrm{P}^{\mathrm{tBu}}{ }_{2} \mathrm{~N}^{\mathrm{Bn}}{ }_{2}\right)\right]^{+}\left(\mathrm{BAr}_{4}{ }_{4}\right)(42)$ reacted with $\mathrm{H}_{2}(1 \mathrm{~atm})$ at room temperature generating complex [( $\left.\left.\mathrm{CpC}_{6} \mathrm{~F}_{5}\right) \mathrm{Fe}\left(\mathrm{P}^{t \mathrm{Bu}}{ }_{2} \mathrm{~N}_{2}{ }_{2}\right)\left(\mathrm{H}_{2}\right)\right]^{+}\left(\mathrm{BAr}_{4}\right)$ (43), which further reacted with DBU to form $\left[\left(\mathrm{CpC}_{6} \mathrm{~F}_{5}\right) \mathrm{Fe}\left(\mathrm{P}^{\mathrm{tBu}}{ }_{2} \mathrm{~N}_{2}^{\mathrm{Bn}}\right)(\mathrm{H})\right]$ (44) [68]. 44 is an electrocatalyst for $\mathrm{H}_{2}$ oxidation with low overpotentials of $160-220 \mathrm{mV}$, and its turnover frequencies reached to $0.66-2.0 \mathrm{~s}^{-1}$, which was the highest for iron complexes.

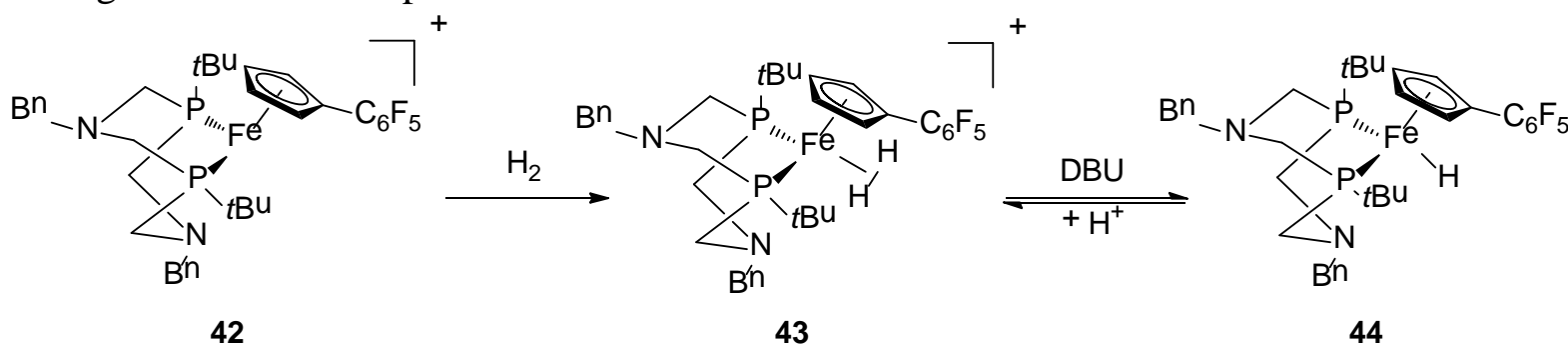

Scheme 21. Reaction of 42 with $\mathrm{H}_{2}$ [68].

\section{Reactions of [Fe]-hydrogenase models with hydrogen}

[Fe]-hydrogenase can activate $\mathrm{H}_{2}$ in the presence of methenyl- $\mathrm{H}_{4} \mathrm{MPT}^{+}$. In the absence of this enzymatic substrate, however, [Fe]-hydrogenase and its extracted Fe-containing co-factor do not react with $\mathrm{H}_{2}$. In recent years many synthetic models of [Fe]-hydrogenase have been reported [4, 27-28, 71]. Some selected examples are shown in Figure 2, and several of them have very similar structure with the [Fe]-hydrogenase [72-79]. However, until now, none of the [Fe]-hydrogenase models can activate $\mathrm{H}_{2}$, even those structurally very similar to the enzyme. The substrate methenyl- $\mathrm{H}_{4} \mathrm{MPT}^{+}$and the protein environment are likely required for $\mathrm{H}_{2}$ activation. A recent theoretical study on this [Fe]-hydrogenase models offers suggestions on how $\mathrm{H}_{2}$ activation might be achieved through incorporation of synthetic ligands [80]. 

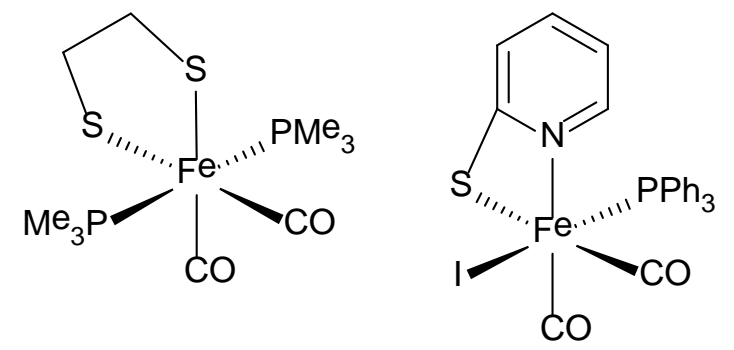<smiles></smiles><smiles></smiles><smiles></smiles>

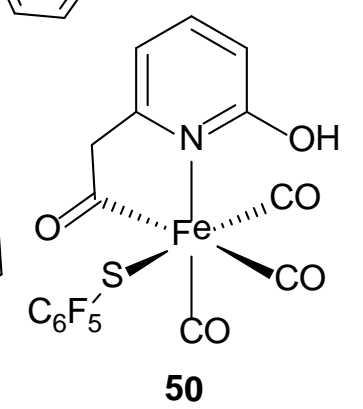

Figure 2. Some selective [Fe]-Hydrogenase models [72-79].

\section{Conclusion}

Among hundreds of structural models of hydrogenases, only a few can activate $\mathrm{H}_{2}$. These models and their reactions with $\mathrm{H}_{2}$ are summarized here. Only a small portion of these $\mathrm{H}_{2}$ activting model complexes, including complexes 1a, 11a, 12, 22, 23, 36, 38, can do it in a catalytic manner, which is important not only as more faithful mimics of hydrogenases, but also relevant to practical applications. Most models only mediate or catalyze heterolytic $\mathrm{H}_{2}$ cleavage without involvement of redox processes. This type of $\mathrm{H}_{2}$ activation is certainly relevant to the reactions of hydrogenases, and can have important applications in hydrogenation and H/D exchange reactions. However, an unique function of [NiFe]- and [FeFe]-hydrogenases is the oxidation of $\mathrm{H}_{2}$ into protons, which is relevant to energy conversion in fuel cells. So far only models 12, 31c, 36, 38 are able to convert $\mathrm{H}_{2}$ into protons in the presence of an oxidant. On the other hand, the bio-inspired models developed by DuBois, Bullock, and co-workers (e.g., complexes $\mathbf{4 0}$ and 44) are quite active for catalytic $\mathrm{H}_{2}$ oxidation. Some of these complexes have been integrated in fuel-cell-like devices [81]. Looking forward, more catalytically active model complexes of hydrogenases, for both hydrogenation and hydrogen oxidation reactions, remain to be developed.

The chemistry summarized here provides insights into the reaction mechanism of hydrogenases and lays important foundations for the development of bio-mimetic $\mathrm{H}_{2}$ activating complexes. However, the application of bio-mimetic compounds in catalytic hydrogenation reactions is largely unexplored. The bio-mimetic hydrogen catalysis is expected to be a fruitful research topic in the near future.

\section{Acknowledgments}

The work at EPFL is supported by the Swiss National Science Foundation (no. 200020_152850/1) and a starting grant from the European Research Council (no. 257096), and the National Natural Science Foundation of China (No. 21302028). 


\section{References}

[1] S. Shima, R.K. Thauer, Chem. Rec. 7 (2007) 37.

[2] P.M. Vignais, B. Billoud, Chem. Rev. 107 (2007) 4206.

[3] J.C. Fontecilla-Camps, A. Volbeda, C. Cavazza, Y. Nicolet, Chem. Rev. 107 (2007) 4273.

[4] C. Tard, C.J. Pickett, Chem. Rev. 109 (2009) 2245.

[5] T.R. Simmons, G. Berggren, M. Bacchi, M. Fontecave, V. Artero. Coord. Chem. Rev. 270-271 (2014) 127.

[6] W. Lubitz, H. Ogata, O. Rüdiger, E. Reijerse, Chem. Rev. 114 (2014) 4081.

[7] J.W. Peters, W.N. Lanzilotta, B.J. Lemon, L.C. Seefeldt, Science 282 (1998) 1853.

[8] Y. Nicolet, C. Piras, P. Legrand, C.E. Hatchikian, J.C. Fontecilla-Camps, Structure 7 (1999) 13.

[9] A.S. Pandey, T.V. Harris, L.J. Giles, J.W. Peters, R.K. Szilagyi, J. Am. Chem. Soc. 130 (2008) 4533.

[10] A. Volbeda, M.-H. Charon, C. Piras, E.C. Hatchikian, M. Frey, J.C. Fontecilla-Camps, Nature 373 (1995) 580.

[11] J. Fritsch, P. Scheerer, S. Frielingsdorf, S. Kroschinsky, B. Friedrich, O. Lenz, C.M.T. Spahn, Nature 479 (2011) 249.

[12] Y. Shomura, K.-S. Yoon, H. Nishihara, Y. Higuchi, Nature 479 (2011) 253.

[13] S. Shima, O. Pilak, S. Vogt, M. Schick, M.S. Stagni, W. Meyer-Klaucke, E. Warkentin, R.K. Thauer, U. Ermler, Science 321 (2008) 572.

[14] W. Lubitz, E. Reijerse, M. van Gastel. Chem. Rev. 107 (2007) 4331.

[15] P.E.M. Siegbahn, J.W. Tye, M.B. Hall. Chem. Rev. 107 (2007) 4414.

[16] J.-F Capon, F. Gloaguen, F.Y. Pétillon, P. Schollhammer, J. Talarmin, Coord. Chem. Rev. 253 (2009) 1476.

[17] Y. Nicolet, A.L. de Lacey, X. Vernede, V.M. Fernandez, E.C. Hatchikian, J.C.FontecillaCamps, J. Am. Chem. Soc. 123 (2001) 1596.

[18] A. Silakov, B. Wenk, E. Reijerse, W. Lubitz, Phys. Chem. Chem. Phys. 11 (2009) 6592.

[19] Ö.F. Erdem, L. Schwartz, M. Stein, A. Silakov, S. Kaur-Ghumaan, P. Huang, S.Ott, E.J. Reijerse, W. Lubitz, Angew. Chem. Int. Ed. 50 (2011) 1439.

[20] G. Berggren, A. Adamska, C. Lambertz, T.R. Simmons, J. Esselborn, M. Atta, S. Gambarelli, J.-M. Mouesca, E. Reijerse, W. Lubitz, T. Happe, V. Artero, M. Fontecave, Nature 499 (2013) 66.

[21] R.D. Bethel, M.Y. Darensbourg, Nature 499 (2013) 40. 
[22] D. Schilter, T.B. Rauchfuss, Angew. Chem. Int. Ed. 52 (2013) 13518.

[23] S.P. Best, Coord. Chem. Rev. 249 (2005) 1536.

[24] A.L. De Lacey, V.M.Fernández, M. Rousset. Coord. Chem. Rev. 249 (2005) 1596.

[25] A.L. De Lacey, V.M. Fernández, Chem. Rev. 107 (2007) 4304.

[26] H. Ogata, K. Nishikawa, W. Lubitz, Nature Doi:10.1038/nature14110.

[27] M.J. Corr, J.A. Murphy, Chem. Soc. Rev. 40 (2010) 2279.

[28] S. Dey, P.K. Das, A. Dey, Coord. Chem. Rev. 257 (2013), 42.

[29] R.M. Bullock, A.M. Appel, M.L. Helm, Chem. Commun. 50 (2014) 3125.

[30] N. Wang, M. Wang, L. Chen, L. Sun, Dalton Trans. 42 (2013) 12059.

[31] S. Kaur-Ghumaan, M. Stein, Dalton Trans. 43 (2014) 9392.

[32] Y. Ohki, K. Tatsumi, Eur. J. Inorg. Chem. 2011 (2011) 973.

[33] D. Sellmann, F. Geipel, M. Moll, Angew. Chem. Int. Ed. 39 (2000) 561.

[34] Y. Ohki, M. Sakamoto, K. Tatsumi, J. Am. Chem. Soc. 130 (2008) 11610.

[35] T. Matsumoto, Y. Nakaya, K. Tatsumi, Angew. Chem. Int. Ed. 47 (2008) 1913.

[36] T. Matsumoto, Y. Nakaya, N. Itakura, K. Tatsumi, J. Am. Chem. Soc. 130 (2008) 2458.

[37] T. Matsumoto, M. Itakura, Y. Nakaya, K. Tatsumi, Chem. Commun. 47 (2011) 1030.

[38] N. Ochi, T. Matsumoto, T. Dei, Y. Nakao, H. Sato, K. Tatsumi, S. Sakaki, Inorg. Chem. 54 (2015) 576.

[39] S. Ogo, R. Kabe, K. Uehara, B. Kure, T. Nishimura, S.C. Menon, R. Harada, S. Fukuzumi, Y. Higuchi, T. Ohhara, T. Tamada, R. Kuroki, Science 316 (2007) 585.

[40] B. Kure, T. Matsumoto, K. Ichikawa, S. Fukuzumi, Y. Higuchi, T. Yagi, S. Ogo, Dalton Trans. (2008) 4747.

[41] K. Kim, T. Kishima, T. Matsumoto, H. Nakai, S. Ogo, Organometallics 32 (2013) 79.

[42] T. Matsumoto, B. Kure, S. Ogo, Chem. Lett. 37 (2008) 970.

[43] S. Ogo, K. Ichikawa, T. Kishima, T. Matsumoto, H. Nakai, K. Kusaka, T. Ohhara, Science 339 (2013) 682.

[44] B.C. Manor, T.B. Rauchfuss, J. Am. Chem. Soc. 135 (2013) 11895.

[45] G.M. Chambers, J. Mitra, T.B. Rauchfuss, M. Stein, Inorg. Chem. 53 (2014) 4243.

[46] J.W. Peters, W.N. Lanzilotta, B.J. Lemon, L.C. Seefeldt, Science 282 (1998) 1853.

[47] Y. Nicolet, C. Piras, P. Legrand, C.E. Hatchikian, J.C. Fontecilla-Camps, Structure 7 (1999) 13. 
[48] H. Reihlen, A. Gruhl, G. Hessling, Liebigs Ann. Chem. 472 (1929) 268.

[49] X. Zhao, I.P. Georgakaki, M.L. Miller, J.C. Yarbrough, M.Y. Darensbourg, J. Am. Chem. Soc., 123 (2001) 9710.

[50] X. Zhao, I.P. Georgakaki, M.L. Miller, R. Mejia-Rodriguez, C.Y. Chiang, M.Y. Darensbourg, Inorg, Chem., 41 (2002) 3917.

[51] I.P. Georgakaki, M.L. Miller, M.Y. Darensbourg, Inorg, Chem., 42 (2003) 2489.

[52] Z.M. Heiden, G. Zampella, L.D. Gioia, T.B. Rauchfuss, Angew, Chem. Int. Ed., 47 (2008) 9756.

[53] S.L. Matthews, D.M. Heinekey, Inorg, Chem., 50 (2011) 7925.

[54] S.L. Matthews, D.M. Heinekey, Inorg, Chem., 49 (2010) 9746.

[55] M. Bruschi, G. Zampella, P. Fantucci, L. De Gioia, Coord. Chem. Rev. 249 (2005) 1620.

[56] M.T. Olsen, B.E. Barton, T.B. Rauchfuss, Inorg, Chem., 48 (2009) 7507.

[57] M.T. Olsen, T.B. Rauchfuss, S.R. Wilson, J. Am. Chem. Soc., 132 (2010) 17733.

[58] J.M. Camara, T.B. Rauchfuss, J. Am. Chem. Soc., 133 (2011) 8098.

[59] J.M. Camara, T.B. Rauchfuss, Nat. Chem, 4 (2012) 26.

[60] N. Wang; M. Wang; T. Zhang; P. Li; J. Liu; L Sun. Chem. Commun. 2008 (2008) 5800.

[61] N. Wang; M. Wang; L. Liu; K. Jin; L. Chen; L. Sun, Inorg. Chem. 48 (2009) 11551.

[62] N. Wang; M. Wang, Y. Wang, D. Zheng, H. Han, M. S. Ahlquist, L. Sun, J. Am. Chem. Soc. 135 (2013) 13688.

[63] M.R. DuBois, D.L. DuBois, Chem. Soc. Rev. 38 (2009) 62.

[64] R.M. Bullock, A.M. Appel, M.L. Helm. Chem. Commun. 50 (2014) 3125.

[65] B. Ginovska-Pangovska, A. Dutta, M.L. Reback, J.C. Linehan, W.J. Shaw, Acc. Chem. Res. 47 (2014) 2621.[66] S.E. Simth, J.Y. Yang, D.L. DuBois, R.M. Bullock, Angew. Chem. Int. Ed. 51 (2012) 3152.

[67] A. Dutta, S. Lense, J. Hou, M.H. Engelhard, J.A.S. Robert, W.J. Shaw, J. Am. Chem. Soc. 135 (2013) 18490.

[68] T. Liu, D.L. DuBois, R.M. Bullock, Nat. Chem. 5 (2013) 228.

[69] T. Liu, X. Wang, C. Hoffmann, D.L. DuBois, R.M. Bullock, Angew. Chem. Int. Ed. 53 (2014) 5300.

[70] T. Liu, S. Chen, M.J. O’Hagan, M.R. DuBois, R.M. Bullock, D.L. DuBois, J. Am. Chem. Soc. 134 (2012) 6257.

[71] K.M. Schultz, D. Chen, X. Hu, Chem. Asian J. 8 (2013) 1068. 
[72] Y. Guo, H. Wang, Y. Xiao, S. Vogt, R.K. Thauer, S. Shima, P.I. Volkers, T.B. Rauchfuss, V. Pelmenschikov, D.A. Case, E.E. Alp, W. Sturhahn, Y. Yoda, S.P. Cramer, Inorg. Chem. 47 (2008) 3969.

[73] B. Li, T. Liu, C.V. Popescu, A. Bilko, M.Y. Darensbourg, Inorg. Chem. 48 (2009) 11283.

[74] T. Liu, B. Li, C.V. Popescu, A. Bilko, L.M. Perez, M.B. Hall, M.Y. Darensbourg, Chem. Eur. J. 16 (2010) 3083.

[75] P.J. Turrell, J.A. Wright, J.N.T. Peck, V.S. Oganesyan, C.J. Pickett, Angew. Chem. Int. Ed. 49 (2010) 7508.

[76] D. Chen, R. Scopelliti, X. Hu, Angew. Chem. Int. Ed. 49 (2010) 7512.

[77] D. Chen, R. Scopelliti, X. Hu, Angew. Chem. Int. Ed. 50 (2011) 5671.

[78] B. Hu, D. Chen, X. Hu, Chem. Eur. J. 20 (2014) 1677.

[79] L.-C. Song, F.-Q. Hu, G.-Y. Zhao, J.-W. Zhang, W.-W. Zhang, Organometallics 33 (2014) 6614.

[80] K. A. Murray, M. D. Wodrich, X. Hu, C. Corminboeuf, Chem. Eur. J. 21 (2015) 3987.

[81] P. D. Tran, A. Morozan, S. Archambault, J. Heidkamp, P. Chenevier, H. Dau, M. Fontecave, A. Martinent, B. Jousselme, V. Artero, Chem. Sci. 6 (2015) 2050. 